\title{
Surface energy budget on Larsen and Wilkins ice shelves in the Antarctic Peninsula: results based on reanalyses in 1989-2010
}

\author{
I. Välisuo ${ }^{1,2}$, T. Vihma ${ }^{1}$, and J. C. King ${ }^{3}$ \\ ${ }^{1}$ Finnish Meteorological Institute, Helsinki,Finland \\ ${ }^{2}$ Departement of Physics, University of Helsinki, Helsinki, Finland \\ ${ }^{3}$ British Antarctic Survey, Cambridge, UK \\ Correspondence to: I. Välisuo (ilona.valisuo@ fmi.fi)
}

Received: 29 January 2013 - Published in The Cryosphere Discuss.: 27 March 2013

Revised: 23 June 2014 - Accepted: 23 June 2014 - Published: 20 August 2014

\begin{abstract}
Ice shelves in the Antarctic Peninsula have significantly disintegrated during recent decades. To better understand the atmospheric contribution in the process, we have analysed the inter-annual variations in radiative and turbulent surface fluxes and weather conditions over Larsen C Ice Shelf (LCIS) and Wilkins Ice Shelf (WIS) in the Antarctic Peninsula in 1989-2010. Three atmospheric reanalyses were applied: ERA-Interim by ECMWF, Climate Forecast System Reanalysis (CFSR) by NCEP, and JRA-25/JCDAS by the Japan Meteorological Agency. In addition, in situ observations from an automatic weather station (AWS) on LCIS were applied, mainly for validation of the reanalyses. The AWS observations on LCIS did not show any significant temperature trend, and the reanalyses showed warming trends only over WIS: ERA-Interim in winter $\left(0.23^{\circ} \mathrm{C} \mathrm{yr}^{-1}\right)$ and JRA-25/JCDAS in autumn $\left(0.13^{\circ} \mathrm{C} \mathrm{yr}^{-1}\right)$. In LCIS from December through August and in WIS from March through August, the variations of surface net flux were partly explained by the combined effects of atmospheric pressure, wind and cloud fraction. The explained variance was much higher in LCIS (up to $80 \%$ ) than in WIS (26-27\%). Summer melting on LCIS varied between 11 and $58 \mathrm{~cm}$ water equivalent (w.e.), which is comparable to previous results. The mean amount of melt days per summer on LCIS was 69 . The high values of melting in summer 2001-2002 presented in previous studies on the basis of simple calculations were not supported by our study. Instead, our calculations based on ERAInterim yielded strongest melting in summer 1992-1993 on both ice shelves. On WIS the summer melting ranged between 10 and $23 \mathrm{~cm}$ w.e., and the peak values coincided with the largest disintegrations of the ice shelf. The amount
\end{abstract}

of melt on WIS may, however, be underestimated by ERAInterim, as previously published satellite observations suggest that it suffers from a significant bias over WIS.

\section{Introduction}

Ice shelves, floating extensions of land ice, are found together with the glaciers and ice sheets with a marine terminus. They have complex interactions with atmosphere, ocean and the feeding glaciers. Ice shelves are sensitive to changes in atmospheric and oceanic circulation and temperatures. In the Antarctic Peninsula, climate warming has been rapid during the last $50 \mathrm{yr}$ and the total ice shelf area has reduced by over $28000 \mathrm{~km}^{2}$ (Cook and Vaughan, 2010). In spite of difficulties related to the large inter-annual variability and brevity of the time series (Chapman and Walsh, 2007), several studies have shown that the warming trend in the Antarctic Peninsula since the 1950s has been stronger than the global average and the average over the rest of the Antarctic continent (King, 1994; Comiso, 2000; Vaughan et al., 2003; Turner et al., 2005; Chapman and Walsh, 2007). The long-term surface temperature trends have been largest on the west coast of the Antarctic Peninsula (Sansom, 1989; Turner et al., 2005). The west coast has more manned observation stations, which increases the reliability of the trends observed. On the east coast of the peninsula, occupied observation stations are very few, but from the abrupt changes in the ice shelf area, it has been suggested that the east coast is also going through major climate changes (Turner et al., 2005). 
The amplification of the warming in the area of the Antarctic Peninsula has been linked, among other things, to changing atmospheric or oceanic circulation, regional air-sea-ice feedbacks (Vaughan et al., 2003; King, 1994) and cloudcover variations (King, 1994). Changes in atmospheric circulation may increase warm-air advection from lower latitudes and enhance the föhn effect of the westerly winds. Changes in ocean circulation could increase the basal melting of the ice shelves. Air-sea-ice interactions and cloud radiative forcing can affect and respond to temperature variations in many ways. These connections are complicated, and identifying the essential driving mechanism is difficult (King, 1994).

Ice shelves influence the global atmosphere-ocean-glacier system in many ways. Calving and basal melt of ice shelves are the most important mass loss mechanisms in Antarctica (Glasser and Scambos, 2008; Depoorter et al., 2013). Calving has previously been considered the most important mass loss mechanism of the ice shelves, but according to Depoorter et al. (2013), basal melt from an ice shelf can account for up to $90 \%$ of the mass balance. Ice shelves influence the dynamics of inland ice and the ocean heat budget, and climatic perturbations cause collapses of ice shelves and are connected to sea level rise. Studies have found evidence of accelerated glacier flow and glacier surges after ice shelf collapse (Rott et al., 2002; Rott et al., 2011; De Angelis and Skvarca, 2003; Rignot et al., 2004), which could contribute to the eustatic sea level rise. The break-up mechanisms of ice shelves are not fully understood, and many processes have been suggested to take part in the collapse. For example, glaciological discontinuities (Braun et al., 2009), surface melting and melt ponds (Braun et al., 2009; van den Broeke, 2005; Scambos et al., 2003), and capsize mechanism (Braun et al., 2009) are believed to be important in the break-up process. The collapses of the ice shelves are believed to be partly caused by atmospheric warming (Rott et al., 1998; Scambos et al., 2000; Shepherd et al., 2003) and increased surface melting (van den Broeke, 2005). Van den Broeke (2005) mentions more specifically that the increase in warm-air advection and the strengthening of the föhn effect, caused by a perturbation in atmospheric circulation, have their share in the decrease in ice shelf area in the Antarctic Peninsula. The effect of ocean temperature has also been pointed out in several studies (Rott et al., 1998; Scambos et al., 2000; Shepherd et al., 2003; Braun et al., 2009). The sea ice concentration might also be related to the state of the ice shelves, but the connection or feedback is believed to be rather complicated (van den Broeke, 2005; King, 1994).

A recent study by Kuipers Munneke et al. (2012) addresses the weather conditions on Larsen C Ice Shelf (LCIS, Fig. 1) and their effect on the ice shelf's surface net flux. They analyse the weather variables measured by two automatic weather stations (AWSs). The observations are also used as input for a surface energy balance model. The model calculations and observations together suggest that the subsurface absorption of solar radiation is important. If the snow

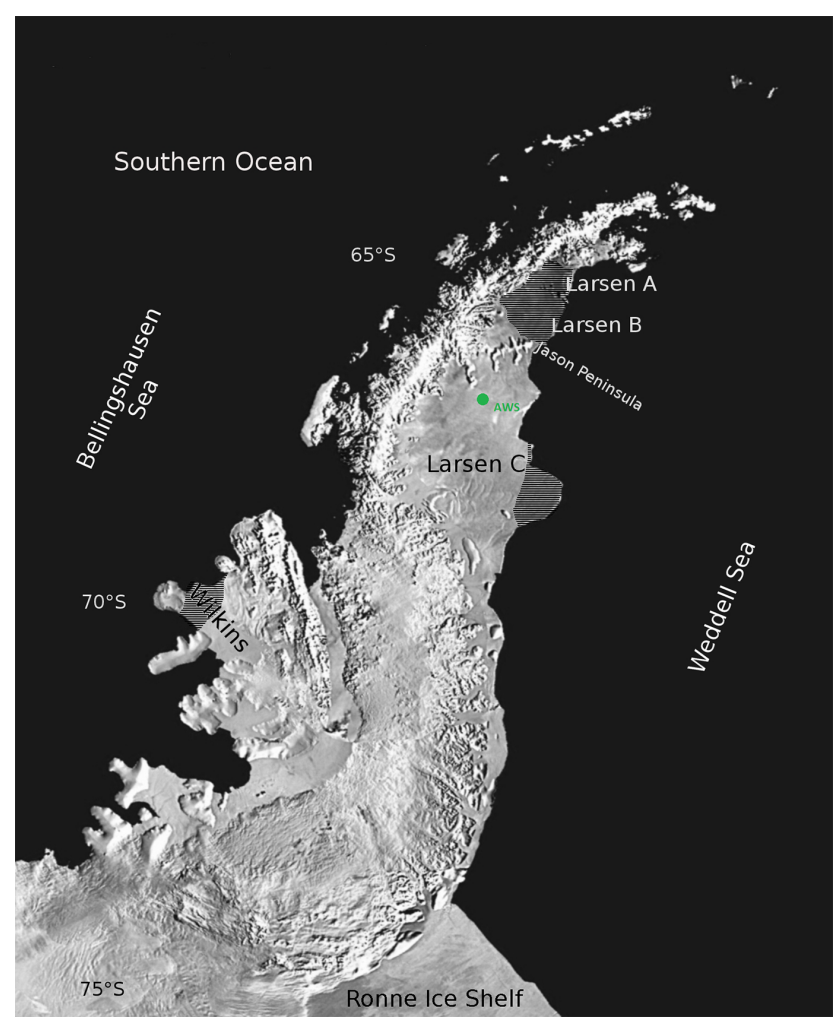

Figure 1. Antarctic Peninsula. Modified from NASA's Blue Marble data set (MODIS AVHRR). The disintegrated parts of Larsen and Wilkins ice shelves are marked as thin stripes, and the location of the automatic weather station used in this study is shown as a green circle.

is cold, penetration of solar radiation warms the snow pack over a certain depth, instead of warming and melting only the surface. In conditions of a warm snowpack, the penetration of solar radiation increases subsurface melting and decreased surface melting, the former being dominant, thus leading to a larger net melt. Kuipers Munneke et al. (2012) also draw attention to the connection between westerly winds and weather conditions on LCIS. Moderate or strong westerly flow over the peninsula leads to northerly flow on the east side of the peninsula (Orr et al., 2004), together with föhn winds, cloudless skies and advection of warm and dry air on the eastern side of the peninsula (Marshall et al., 2006; van Lipzig et al., 2008). Recently, Kuipers Munneke et al. (2012) presented a case in November 2010 with warm föhn wind and sunny conditions on LCIS. During that period the increase in shortwave radiation and sensible heat flux outweighed the decrease in longwave radiation and latent heat flux.

In the previous studies addressing the evolution of ice shelves, different limits for the viability of the ice shelves have been proposed. Many have agreed that the annual mean near-surface temperature should be $-9{ }^{\circ} \mathrm{C}$ or lower for an ice shelf to survive (Mercer, 1978; Vaughan and Doake, 1996; 
Vaughan et al., 2003; Rott et al., 1996, 1998; Morris and Vaughan, 2003). Also, the summertime isotherm of $0^{\circ} \mathrm{C}$ has been suggested to be the temperature limit below which the ice shelves would be viable (Mercer, 1978). In year 2000, the $-9^{\circ} \mathrm{C}$ annual isotherm crossed the south-western parts of Wilkins Ice Shelf (WIS) on the western side of the peninsula and on Jason Peninsula on the eastern side. Larsen B Ice Shelf on the northern side of Jason Peninsula had an annual mean temperature higher than $-9^{\circ} \mathrm{C}$ and LCIS and Larsen $\mathrm{D}$ on the southern side were colder than $-9^{\circ} \mathrm{C}$ (Cook and Vaughan, 2010).

LCIS and WIS are located about 300-400 km apart, and they experience remarkably different weather conditions. The west side of the peninsula, where WIS is located, is exposed to the warm and humid westerly winds from the Southern Ocean. On the eastern side of the peninsula, Larsen ice shelves are confronting colder and drier climate due to the continental air masses flowing from West Antarctica and Coats Land to Ronne Ice Shelf and further to the Weddell Sea (King and Turner, 1997). Furthermore, LCIS and WIS have different structures and mechanical characteristics (Braun et al., 2009).

In January 2008 the area of the WIS was $13000 \mathrm{~km}^{2}$, which was reduced by almost $2000 \mathrm{~km}^{2}$ by the collapses in February, May and June. In April 2009 an ice bridge connecting the ice shelf to Charcot Island gave in. WIS gains mass mainly by direct accumulation and loses mass by basal melt (Braun et al., 2009). Some zones on the ice shelf also encounter intense surface melting. The mean horizontal velocities on WIS are very small, but the accumulation rate is relatively high. WIS is characterised by a very large number of ice rises and by connections to the confining islands. The bulk temperature of the ice is high on WIS, which indicates a weaker ice matrix (Braun et al., 2009). During the last decades, WIS has experienced several major break-up events ranging from 20 to $1200 \mathrm{~km}^{2}$ (Braun et al., 2009).

The surface area of LCIS is $51000 \mathrm{~km}^{2}$, which makes it the largest ice shelf on the Antarctic Peninsula (Cook and Vaughan, 2010). It has 12 major flow units or ice shelf domains (Glasser et al., 2009). Contrary to WIS, the input glaciers are fast-flowing and contribute actively to the mass balance of the ice shelf (Glasser et al., 2009). On the ice shelf, two main kinds of rift systems are observed: tributary glacier rift systems and ice shelf edge rifts. No large-scale changes, at least, in the location of rifts and crevasses have been observed between 2002 and 2007. The overall changes in the ice shelf have been small during the last two decades, although the ice shelf edge shows a gradual recession. On the basis of the residence time of the ice on the ice shelf, it has been estimated that LCIS has existed in its present configuration for at least $560 \mathrm{yr}$ (Glasser et al., 2009). In the future LCIS is presumed to stay stable, with cyclical calving and regrowth; an imminent collapse of LCIS is thought to be unlikely (Glasser et al., 2009; Jansen et al., 2010). Future changes could be dominated by gradual thinning of the ice shelf (Shepherd et al., 2003).

In this paper, the weather conditions and surface fluxes on LCIS and WIS are studied using atmospheric reanalyses. Our primary objective is to find out (1) how the net surface heat flux (sum of radiative and turbulent surface fluxes) varies inter-annually, (2) how the flux variations are related to large-scale weather conditions, (3) how much summer melt the net heat flux generates, and (4) how the summer melt varies inter-annually and compares with the observed disintegration events of the ice shelves.

\section{Material and methods}

\subsection{Atmospheric reanalyses}

In atmospheric reanalyses, the majority of available observations are combined with state-of-the-art modelling solutions to obtain the best estimate for the real state of climate in the past and present. The advantages of reanalyses are good temporal and spatial coverage, as well as good consistency. In reanalyses, errors and artificial trends caused by model and data assimilation changes are avoided, but changes in observation systems can cause complications (Saha et al., 2010; Bengtsson et al., 2007). Saha et al. (2010) emphasise that one single reanalysis does not suffice for achieving a reliable picture on the real state of the atmosphere due to changes in observations and input data, and due to the different possibilities in models and data assimilation solutions.

In this study we apply three reanalyses: ERA-Interim (Dee et al., 2011), NCEP-CFSR (Saha et al., 2010) and JRA-25/JCDAS (Onogi et al., 2007), summarised in Table 1. ERA-Interim (ERAI from here), a reanalysis by the European Centre for Medium-Range Weather Forecasts (ECMWF), has been created as an intervening step between the former ERA-40 reanalysis and an upcoming reanalysis. When this study was started, ERAI covered the years from 1989 to 2010 . Its horizontal resolution is T255 ( 79 km) and it has 60 hybrid sigma-pressure vertical levels, of which the lowest is at approximately $10 \mathrm{~m}$. ERAI applies fourdimensional variational data assimilation (4D-VAR). Climate Forecast System Reanalysis, CFSR, is developed by the National Centers for Environmental Prediction (NCEP), USA. Its time range is from 1979 to present. The horizontal resolution is T382 ( $\sim 38 \mathrm{~km})$ and the number of vertical levels is 64 in sigma-pressure hybrid layers. The data assimilation technique is 3D-VAR. The Japanese 25-year Reanalysis was conducted in collaboration with Japan Meteorological Agency (JMA) and the Central Research Institute of Electric Power Industry (CRIEPI). The reanalysis was first made for a 25 yr period from 1979 to 2004, after which it was continued with an identical set-up from 2005 to present. The continuation part is called JCDAS. From here on we will refer to both parts of the reanalysis as JRA. The horizontal 
resolution of JRA is T106 $(\sim 120 \mathrm{~km})$ and the number of vertical hybrid sigma-pressure model levels is 40 . A recent study by Cullather and Bosilowich (2012) noted that ERAI and CFSR have better surface parameterisation and agree to larger extents with surface flux measurements than the novel Modern-Era Retrospective Analysis for Research and Applications (MERRA) reanalysis. MERRA is based on the Goddard Earth Observing System (GEOS) atmospheric model and data assimilation system, and released by the National Aeronautics and Space Administration (NASA) Global Modeling and Assimilation Office (GMAO) (Rienecker et al., 2011). Despite the good parameterisations, ERAI and CFSR disagree with observations of surface fluxes and atmospheric boundary-layer variables in polar regions, at least by underestimation of the surface net flux (Cullather and Bosilowich, 2012) and overestimation of the near-surface temperature in the Arctic (Jakobson et al., 2012).

Radiative and turbulent surface fluxes and basic weather variables were collected from the three reanalyses. The surface fluxes (incoming and outgoing solar and thermal radiation, sensible and latent heat flux) are acquired from short-term forecasts without data assimilation. The weather variables (skin temperature (here only ERAI), $2 \mathrm{~m}$ temperature, $10 \mathrm{~m}$ wind components, mean sea level air pressure and cloudiness (here only ERAI)) are analysis products. The surface data collected in the vicinity on the ice shelves go partly into the production of the reanalyses. All three reanalyses used the observations of the surface pressure, but only ERAI assimilates the $2 \mathrm{~m}$ temperature measurements (Uppala et al., 2005; Onogi et al., 2007; Saha et al., 2010). We used the monthly mean products, and further calculated annual and seasonal means for summer (DecemberFebruary), autumn (March-May), winter (June-August), and spring (September-November). The areal means over LCIS and WIS were calculated for each variable. This was done by selecting the relevant grid points for LCIS and WIS and calculating the mean value from those. Since all the three reanalyses had different resolution, the areal averaging was done individually for each reanalysis. To have a consistent basis for the study, only such grid points were included which lie on the presently existing parts of the ice shelves. As the low resolution of the reanalyses smoothes the orography of the Antarctic Peninsula, there was up to $20 \mathrm{~m}$ difference between the true surface orography (elevation from sea level at the AWS location) and reanalyses.

\subsection{Validation sources}

\subsubsection{Larsen C Ice Shelf AWS}

The validation of reanalyses was done using data from an AWS on LCIS. The AWS is located at $67.012^{\circ} \mathrm{S}, 61.55^{\circ} \mathrm{W}$ and operated by the British Antarctic Survey. The AWS measurements are compared against the nearest grid point in the reanalyses. The station was initially deployed in Octo- ber 1985 and has been in operation ever since. The AWS measures air temperature, pressure, wind speed and direction, and relative humidity. From January 2009, the AWS also measured downwelling and upwelling short- and longwave radiative fluxes. However, no direct measurements of the turbulent fluxes are available.

\subsubsection{Surface fluxes from Van den Broeke (2005)}

For calculating the melt we applied a method very similar to the one used by Van den Broeke (2005). Van den Broeke used observations from Larsen C AWS to calculate the surface melt and to assess the melt condition prior to the collapse of Larsen B Ice Shelf. In addition to using the same method as Van den Broeke, we compared the results to those in Van den Broeke (2005).

\subsubsection{Melt fluxes from Barrand et al. (2013)}

For the validation of the melt calculations, we compared our results to those in a study by Barrand et al. (2013). Barrand et al. (2013) present the melt trends on Antarctic Peninsula ice shelves based on satellite observations. They used QuikSCAT (hereafter QSCAT) (Long and Hicks, 2010) daily enhanced-resolution, slice-based scatterometer image reconstruction (SIR) images (Early and Long, 2001; Long and Hicks, 2010) with nominal pixel size of $2.225 \mathrm{~km}$ and estimated effective resolution of $\sim 5 \mathrm{~km}$. Their study covered the trends in melt onset date, melt season duration, and the melt strength and extent.

\section{Validation}

\subsection{Validation of reanalyses}

Our primary objective in validation is to understand how well the three reanalyses can reproduce the observed inter-annual variations over the ice shelves. Results of ERAI, CFSR and JRA were compared against the AWS observations on the air temperature and horizontal wind components. The wind was observed at the height at $3 \mathrm{~m}$ above the snow surface, whereas the reanalyses output was from the height of $10 \mathrm{~m}$. A height correction was done by applying the logarithmic wind profile, assuming an aerodynamic roughness length of $0.1 \mathrm{~mm}$ (no information on stability was available). No height correction was calculated for air temperature, because the height difference between the measured values (height of $3 \mathrm{~m}$ ) and reanalysis outputs $(2 \mathrm{~m})$ was so small. The validation was performed for the seasonal averages from austral autumn 1989 to austral autumn 2010.

The results for the seasonal means reveal that for the nearsurface temperature, the best performance, ranked on the basis of bias and root-mean-squared error (RMSE), is achieved in summer (December-February, Table 2). The summertime temperature correlations range from 0.43 (ERAI) to 0.61 
Table 1. Description of the reanalyses products used in this study.

\begin{tabular}{|c|c|c|c|}
\hline & ERAI & CFSR & JRA \\
\hline Time range & 1989-present & 1979-present & 1979-present \\
\hline Assimilation & 4D-VAR & 3D-VAR & 3D-VAR \\
\hline Horizontal resolution & ca. $79 \mathrm{~km}$ & ca. $38 \mathrm{~km}$ & ca. $120 \mathrm{~km}$ \\
\hline $\begin{array}{l}\text { Number of vertical lev- } \\
\text { els }\end{array}$ & 60 & 64 & 40 \\
\hline $\begin{array}{l}\mathrm{T} 2 \mathrm{~m}, \quad \mathrm{u} 10 \mathrm{~m}, \quad \mathrm{v} 10 \mathrm{~m}, \\
\text { mslp, cloud fraction }\end{array}$ & analysis & analysis & analysis \\
\hline Tskin, cloud fraction & analysis & not used & not used \\
\hline $\begin{array}{l}\text { Radiative and turbulent } \\
\text { surface fluxes: SWin, } \\
\text { SWout, LWin, LWout, } \\
\text { H, LE }\end{array}$ & $\begin{array}{l}- \text { monthly means based on } \\
6 \mathrm{~h} \text { accumulated forecasts (fc) } \\
\text { (used in Sects. } 3.1-3.3 .3 \text { ) } \\
-6 \mathrm{~h} \text { accumulated fc, calculated } \\
\text { by the authors, based on } 12 \text { and } \\
18 \mathrm{~h} \text { accumulated fc with the } \\
\text { first } 6 \mathrm{~h} \text { not included (used in } \\
\text { Sect. } 3.4 \text { ) }\end{array}$ & $\begin{array}{l}\text { - monthly means based on } \\
\text { accumulated } 6 \mathrm{~h} \mathrm{fc} \text { (used in } \\
\text { Sects. } 3.1-3.3 .3 \text { ) } \\
-6 \mathrm{~h} \text { accumulated fc (used in } \\
\text { Sect. 3.4) }\end{array}$ & $\begin{array}{l}\text { - monthly means based on } \\
\text { accumulated } 6 \mathrm{~h} \text { fc (used in } \\
\text { Sects. } 3.1-3.3 .3 \text { ) } \\
\text { - } 6 \mathrm{~h} \text { accumulated fc (used in } \\
\text { Sect. 3.4) }\end{array}$ \\
\hline Surface net flux & $\begin{array}{l}\text { Calculated by the authors on the } \\
\text { basis of radiative and turbulent } \\
\text { surface fluxes }\end{array}$ & $\begin{array}{l}\text { Calculated by the authors on the } \\
\text { basis of radiative and turbulent } \\
\text { surface fluxes }\end{array}$ & $\begin{array}{l}\text { Calculated by the authors on the } \\
\text { basis of radiative and turbulent } \\
\text { surface fluxes }\end{array}$ \\
\hline $\begin{array}{l}\text { Surface melt and num- } \\
\text { ber of melt days }\end{array}$ & $\begin{array}{l}\text { Calculated by the authors on the } \\
\text { basis of the net flux }\end{array}$ & not calculated & not calculated \\
\hline
\end{tabular}

(CFSR). The correlation for ERAI is even better (0.71) in winter, June-August, but the biases of all reanalyses are more than doubled compared to summer (Table 2). During the melt periods the temperature bias was smaller, $1.7^{\circ} \mathrm{C}$ (ERAI, $2 \mathrm{~m}$ ), suggesting that the melt calculations are less crucially affected by the bias. There are two evident reasons for smaller bias during the melt season. The first reason is that, during the melt season, the surface temperature is limited to melting point, which also limits the near-surface temperature. Secondly, in wintertime, surface inversions are common and the limitations in modelling the stable atmospheric boundary layer might produce biased near-surface temperatures.

The eastward $(U)$ and northward $(V)$ wind components perform best in summer. For $U$, the biases are positive, i.e. all reanalyses overestimate the strength of the westerly wind on LCIS. For $V$ the bias is mostly negative. JRA stands out for the highest correlations for the $U$ component, although the temperature and $V$ wind correlations are mostly weaker than for ERAI and CFSR.

For a shorter time period from 22 January 2009 to 27 April 2010 , the solar and thermal surface flux products were validated against flux measurements performed by the British Antarctic Survey on LCIS (same location as the AWS). To avoid artificially high correlations caused by the diurnal variations, we calculated $24 \mathrm{~h}$ averages from the reanalyses and measurements, and further removed the annual cycle before calculating the correlation. The results (Table 3) suggest that, with respect to bias and RMSE ERAI and CFSR performed especially well for the net solar radiation, which is the key factor in the surface energy balance. This bias was only $0.2 \mathrm{Wm}^{-2}$ in ERAI. The surface net solar radiation in the reanalyses is affected not only by the surface albedo parameterisations but also largely by the radiative transfer in the atmosphere and the cloudiness. As the surface on the ice shelves is either snow or ice, the albedo depends on parameterisation of snow and ice albedos. Parameterisations of those properties have been summarised by Pirazzini (2009). ERAI applies the ECMWF albedo parameterisation (ECMWF, 2007), where the snow albedo is a function of temperature. CFSR uses the CAM2 parameterisation (Collins et al., 2002), where snow albedo is wave-band- and temperature-dependent. JRA employs the albedo parameterisation by Sellers et al. (1986), which is a simplified function of temperature and wave length. We calculated the surface albedo as the ratio of the reflected and incoming solar radiation and presented it in Table 3. In order to avoid too low sun angles, we calculated the albedo only when the incoming solar radiation was larger than $100 \mathrm{Wm}^{-2}$. Considering the bias, ERAI and NCEP agreed reasonably well with the observations, whereas JRA underestimated the albedo during the validation period. None of the albedos from the reanalyses 
Table 2. Validation of reanalyses against AWS observations on LCIS. The correlations are calculated for inter-annual variations of seasonal means.

\begin{tabular}{rlrrr|rrrr|rrr|r|r}
\hline & & \multicolumn{3}{c}{ ERAI } & \multicolumn{3}{c}{ JRA } & & & CFSR & AWS \\
\cline { 3 - 11 } & & $R$ & Bias & RMSE & $R$ & Bias & RMSE & $R$ & Bias & RMSE & Mean \\
\hline \multirow{2}{*}{ Temp. } & DJF & 0.43 & 2.4 & 3.0 & 0.51 & 1.3 & 2.3 & 0.61 & -0.7 & 1.9 & -2.7 \\
& MAM & 0.25 & 5.3 & 5.8 & -0.04 & 4.7 & 2.3 & 0.09 & 3.2 & 4.7 & -16.5 \\
& JJA & 0.71 & 4.9 & 5.4 & 0.39 & 3.6 & 5.8 & 0.21 & 3.0 & 4.5 & -22.0 \\
& SON & 0.53 & 3.3 & 4.0 & 0.29 & 2.7 & 5.1 & 0.49 & 1.3 & 2.6 & -12.5 \\
\hline$U$ & DJF & 0.46 & 0.5 & 0.8 & 0.63 & 0.6 & 1.0 & -0.10 & 0.6 & 1.0 & -0.03 \\
& MAM & 0.03 & 1.2 & 1.7 & 0.15 & 0.2 & 1.3 & 0.13 & 0.4 & 1.0 & 1.5 \\
& JJA & 0.37 & 1.6 & 1.7 & 0.39 & 0.7 & 1.4 & 0.11 & 0.4 & 0.9 & 0.8 \\
& SON & -0.14 & 1.2 & 1.8 & 0.09 & 1.3 & 2.1 & -0.07 & 0.6 & 1.4 & 0.7 \\
\hline \multirow{2}{*}{$V$} & DJF & 0.37 & -0.3 & 0.8 & 0.36 & 0.5 & 0.9 & 0.43 & 0.3 & 0.8 & -0.2 \\
& MAM & 0.56 & -0.9 & 1.1 & 0.03 & -0.4 & 1.2 & 0.37 & -0.9 & 1.2 & -0.05 \\
& JJA & 0.33 & -0.6 & 1.1 & 0.10 & 0.2 & 1.0 & 0.26 & -0.5 & 1.0 & 0.1 \\
& SON & 0.07 & -0.8 & 1.2 & 0.17 & -0.3 & 0.9 & 0.25 & -0.5 & 1.0 & 0.4 \\
\hline
\end{tabular}

correlated well with the observations. We assume that this is due to the faster temporal variations of the observed albedo, which were not captured by the reanalyses.

In terms of longwave radiation, ERAI and CFSR perform reasonably well, albeit not as well as for the solar radiation. For them the bias for net longwave radiation is between -16 and $-18 \mathrm{Wm}^{-2}$. JRA instead suffers from a bias of $-36 \mathrm{Wm}^{-2}$ for the net thermal radiation. A bias of this order of magnitude is probably related to errors in clouds, but, in lieu of cloud observations, we do not have means to prove this.

The turbulent surface fluxes were validated by Tastula et al. (2013) over the western Weddell Sea. They showed that the ERAI sensible heat flux had a positive bias of $6 \mathrm{Wm}^{-2}$, which was partly balanced by a negative bias of $-3 \mathrm{Wm}^{-2}$ in the latent heat flux.

As a summary, the capability of reanalyses to reproduce the observed inter-annual variations (of seasonal means) was found satisfactory for the air temperature, but worse for the wind, based on the lower average correlations of the wind (Table 2). ERAI has the highest overall correlation with the seasonal temperature mean values, which indicates that despite the temperature bias, ERAI produces the inter-annual temperature variation most reliably. For the surface radiative fluxes, ERAI and CFSR clearly performed better than JRA. We note that also AWS observations are subject to errors, which may be caused, among other things, by solar heating of the temperature sensors as well as snow and ice accretion in the anemometer. Hence, the results presented in Tables 2 and 3 contain uncertainties, but should give an idea of the relative performance of the three reanalyses, in particular when we focus on the correlations. This is because observation errors most probably do not increase correlations, although in some cases they may reduce the bias and RMSE.

\subsection{Validation of surface energy budget}

The reanalysis products can also be compared against the AWS observations of Kuipers Munneke et al. (2012) from LCIS in February 2009-January 2011. The surface fluxes presented by Kuipers Munneke et al. (2012) are included in Table 4, together with the reanalyses fluxes. In all three reanalyses in all seasons, the net shortwave radiation was larger than in the AWS data. Also, the net longwave radiation, which was negative year-round, had a larger magnitude in the reanalyses. Also the turbulent sensible heat flux was larger (and positive around the year) in the reanalyses than in the AWS data, and the latent heat flux, which was negative year-round in the reanalyses, had a larger magnitude in the reanalyses than in the AWS data. At the latter, the latent and sensible heat fluxes changed sign in the course of the year. The seasonal mean net flux (sum of radiative and turbulent fluxes) is close to zero in the three reanalyses and in the observations. At the annual level, all the reanalyses underestimate the longwave radiative flux and overestimate shortwave and sensible heat fluxes. This pattern of over- and underestimation is present also in summer (DJF). These biases compensate for each other in ERAI especially, and possibly explain the good values obtained from the melt calculations later in the study.

We note, however, that the AWS observations of radiative fluxes may include errors due to accumulation of frost, condensed water, and snow on the domes of the radiation sensors. Further, the turbulent fluxes were not directly measured but parameterised on the basis of observations of the air and surface temperature, air humidity and wind speed, which reduces their accuracy. 
Table 3. Validation of the radiative fluxes of the reanalyses against observations for the time period from 22 January 2009 to 31 December 2009 at a time resolution of $6 \mathrm{~h}$. For the correlation coefficients, however, the diurnal and annual cycles were removed in order to avoid artificially high values. Albedo was calculated only when $\mathrm{SWin}>100 \mathrm{Wm}^{-2}$.

\begin{tabular}{lrrr|rrr|rrr|r}
\hline & \multicolumn{3}{c}{ ERAI } & \multicolumn{3}{c}{ JRA } & \multicolumn{3}{c}{ CFSR } & AWS \\
\cline { 2 - 9 } & $R$ & Bias & RMSE & $R$ & Bias & RMSE & $R$ & Bias & RMSE & Mean \\
\hline SWin & 0.61 & -13.2 & 57.5 & 0.52 & -1.0 & 46.9 & 0.59 & -2.8 & 43.6 & 142 \\
SWout & 0.66 & -12.6 & 42.1 & 0.56 & -23.8 & 53.1 & 0.67 & -1.5 & 32.3 & 113 \\
SWnet & 0.36 & 0.2 & 23.4 & 0.21 & 24.3 & 55.1 & 0.25 & -1.2 & 19.5 & 23 \\
LWin & 0.70 & 5.2 & 32.8 & 0.50 & -13.2 & 40.0 & 0.75 & -2.9 & 26.9 & 236 \\
LWout & 0.60 & 23.4 & 32.5 & -0.1 & 22.7 & 32.9 & 0.66 & 12.6 & 24.4 & 249 \\
LWnet & 0.52 & -18.1 & 28.2 & 0.2 & -35.9 & 45.3 & 0.59 & -15.5 & 26.4 & -14 \\
Albedo & 0.17 & -0.02 & 0.1 & 0.03 & -0.1 & 0.2 & 0.01 & 0.002 & 0.06 & 0.83 \\
(SWout/SWin) & & & & & & & & & & \\
\hline
\end{tabular}

\subsection{Validation of melt flux}

Barrand et al. (2013) present the melt trends on Antarctic Peninsula ice shelves based on QSCAT satellite observations. According to Barrand et al. (2013), the number of melt days retrieved from QSCAT were in agreement with positive station temperatures. The melt season duration and the amount of surface melt can be directly compared to our study. The melt season duration on LCIS and WIS from QSCAT (Barrand et al., 2013) is presented in Fig. 2, together with the number of melt days calculated from ERAI. On LCIS the number of melt days from ERAI agrees well with the melt season duration from QSCAT. On WIS the melt products are well correlated, but ERAI underestimates the number of melt days by around $30 \%$. A possible reason for the bias on WIS is the small size of WIS, due to which the melt patterns might not be resolved at the resolution of ERAI. In reality WIS is at a lower elevation than the surrounding islands, and the coarse resolution of ERAI might affect the altitude of WIS in the reanalysis. Barrand et al. (2013) note also that the melt season over WIS is unusually long compared to the average of the same latitude.

According to Barrand et al. (2013) the melt season duration (MD) showed large inter-annual variability between 1999 and 2009. They state that negative MD anomalies (shorter melt seasons) occurred on Larsen $\mathrm{C}$ and Wilkins ice shelves in 2004 (i.e. summer 2003-2004). Positive anomalies occurred on WIS in 2000, in the vicinity of Larsen B and Larsen C ice shelves during 2002, throughout the southern Larsen C and Larsen D in 2003, and throughout Larsen C in 2006 and 2008.

In our melt calculation (during QSCAT era in 1999-2009) based on ERAI, we observed negative anomalies in the number of melt days (analogous with melt season duration) on LCIS in the summers of 2000-2001 and 2003-2004. On WIS, short melt seasons were observed in 1999-2000 and 2003-2004. The negative anomalies in the summers of 2000 2001 (WIS) and 2003-2004 (LCIS and WIS) occurred both in our calculations and in Barrand et al. (2013).
Positive anomalies in number of melt days occurred on LCIS in 2001-2002, 2004-2005, 2005-2006 and 2006-2007 and on WIS in 2004-2005 and 2006-2007. Of the positive anomalies, the summers of 1999-2000 (WIS), 2002 (LCIS), and 2006 (LCIS) were also identified by Barrand et al. (2013).

A large number of consistent results were identified between our melt studies and the satellite observations presented by Barrand et al. (2013). Exceptions were in 2006 and 2008, when Barrand et al. (2013) observed a long MD on southern Larsen C and Larsen D and over all of Larsen C, respectively. Our different results in 2006 might be caused by the lower resolution of ERAI and the fact that Larsen D was out of our study area. Also, we did not study the spatial difference in melt within the ice shelves. In the study by Barrand et al. (2013), the RACMO2 model did not capture all of the long or short melt season either. One reason was discussed to be the coarse resolution of RACMO. Although ERAI's purpose of use and operational principles are different from RACMO, the resolution plays an important role especially in the regions where the ice shelf is covered by only a few model grid points. Barrand et al. (2013) also discuss how the occurrence of melt ponds affects the satellite based melt observations. They state that WIS particularly experiences persistent multi-year seasonal surface melt ponds. In the satellite products the activation of the melt ponds is interpreted as the start of the melt season, which results in observing a longer melt season. This can partly explain why the satellites products show several longer melt seasons, particularly on WIS.

\section{Results}

\subsection{Results on temporal evolution}

Our focus is on the surface energy fluxes and weather conditions on LCIS and WIS. The investigation of surface fluxes is limited to net solar radiation, net thermal radiation, sensible 
Table 4. Seasonal mean values of the surface fluxes on Larsen C and Wilkins ice shelves averaged from 1 January 1989 to 31 December 2009. Here LW is the net longwave radiation, SW the net shortwave, SH the sensible heat flux, LH the latent heat flux and NF the sum of these components. Due to the rounding-off, NF is not always exactly equal to the sum of its seasonal components. The AWS section shows the seasonal means from the Utrecht University AWS on Larsen C Ice Shelf $\left(67^{\circ} 00.8^{\prime} \mathrm{S}, 61^{\circ} 28.8^{\prime} \mathrm{W}\right)$ from 1 February 2009 to 31 January 2011. The AWS measurements are adopted from Kuipers Munneke et al. (2012).

\begin{tabular}{|c|c|c|c|c|c|c|c|c|c|c|c|}
\hline \multicolumn{6}{|c|}{ Larsen C } & \multicolumn{6}{|c|}{ Wilkins } \\
\hline ERAI & DJF & MAM & JJA & SON & Ann. & ERAI & DJF & MAM & JJA & SON & Ann. \\
\hline LW & -43 & -28 & -31 & -42 & -36 & LW & -42 & -32 & -29 & -37 & -35 \\
\hline SW & 59 & 8 & 1 & 33 & 25 & SW & 59 & 8 & 1 & 27 & 24 \\
\hline $\mathrm{SH}$ & 3 & 9 & 15 & 9 & 9 & SH & 2 & 7 & 8 & 4 & 5 \\
\hline LH & -9 & -2 & -1 & -6 & -4 & LH & -10 & -4 & -2 & -6 & -5 \\
\hline $\mathrm{NF}$ & 10 & -13 & -15 & -6 & -6 & $\mathrm{NF}$ & 8 & -21 & -21 & -12 & -12 \\
\hline JRA & DJF & MAM & JJA & SON & Ann. & JRA & DJF & MAM & JJA & SON & Ann. \\
\hline LW & -50 & -39 & -40 & -51 & -45 & LW & -51 & -39 & -41 & -51 & -46 \\
\hline SW & 84 & 12 & 2 & 46 & 36 & SW & 102 & 12 & 1 & 50 & 41 \\
\hline $\mathrm{SH}$ & 4 & 8 & 24 & 14 & 15 & SH & 4 & 22 & 25 & 15 & 16 \\
\hline LH & -11 & -1 & 0 & -6 & -4 & LH & -13 & -3 & 0 & -9 & -6 \\
\hline $\mathrm{NF}$ & 26 & -10 & -14 & 3 & 2 & NF & 41 & -9 & -15 & 5 & 5 \\
\hline CFSR & DJF & MAM & JJA & SON & Ann. & CFSR & DJF & MAM & JJA & SON & Ann. \\
\hline LW & -36 & -31 & -33 & -40 & -35 & LW & -37 & -28 & -28 & -35 & -32 \\
\hline SW & 52 & 9 & 1 & 34 & 24 & SW & 60 & 9 & 1 & 34 & 26 \\
\hline $\mathrm{SH}$ & 9 & 23 & 30 & 18 & 20 & SH & 9 & 18 & 18 & 13 & 15 \\
\hline LH & -19 & -4 & -4 & -12 & -9 & LH & -14 & -8 & -7 & -13 & -11 \\
\hline $\mathrm{NF}$ & 7 & -3 & -5 & -1 & 0 & NF & 19 & -9 & -16 & -2 & -2 \\
\hline AWS & DJF & MAM & JJA & SON & Ann. & & & & & & \\
\hline LW & -21.1 & -8.6 & -9.8 & -23.3 & -15.7 & & & & & & \\
\hline SW & 38.0 & 6.2 & 1.0 & 26.5 & 17.8 & & & & & & \\
\hline $\mathrm{SH}$ & -5.0 & 0.3 & 7.1 & 3.6 & 1.5 & & & & & & \\
\hline LH & -9.6 & -0.2 & 1.0 & -4.0 & -3.2 & & & & & & \\
\hline NF & 2.3 & -2.3 & -0.7 & 2.8 & 0.4 & & & & & & \\
\hline
\end{tabular}

heat flux and latent heat flux, which together describe the heat exchange between the surface and the atmosphere. The sub-surface heat flux, i.e. the conductive heat flux between the surface and deeper layers in the snow, was not taken into account. The weather variables in consideration are the $2 \mathrm{~m}$ air temperature, $10 \mathrm{~m}$ wind components, and mean sea level pressure. The time series of monthly mean values are presented and trends of seasonal and annual mean values are calculated. Notice is taken of the weather conditions that favour particularly large or small surface energy fluxes.

\subsection{Time series}

The time series of surface energy fluxes are presented in Fig. 3. The turbulent fluxes of sensible and latent heat are small in each reanalysis and on both ice shelves. They are of opposite sign throughout the year, the sensible heat flux being towards the snow surface (defined as the positive direction) and the latent heat flux from snow to air (negative). The net solar radiation differs a lot between the three reanaly- ses. The lowest summertime net solar radiations are obtained from CFSR, and the largest ones from JRA. The values from ERAI are close to those of CFSR, but show a much larger inter-annual variation. The net solar radiation has a tendency to be slightly larger on WIS than on LCIS.

The net flux varies on both sides of zero in all reanalyses. There are major differences in the seasonal cycle of the net flux between the reanalyses and regions. ERAI shows the largest inter-annual variation in the net flux, but the mean values are comparable to the other reanalyses. The differences in inter-annual variability can be quantified with the standard deviations of the surface net flux from the $20 \mathrm{yr}$ mean. In ERAI, the standard deviations of the annual means of the surface net flux are $3.65 \mathrm{Wm}^{-2}$ (LCIS) and $2.32 \mathrm{Wm}^{-2}$ (WIS). The $20 \mathrm{yr}$ seasonal mean values of the surface fluxes reveal that the fluxes vary more between the reanalyses than between the areas (Table 4).

All the three reanalyses show a roughly similar behaviour in $2 \mathrm{~m}$ temperature (Fig. 4). The largest differences between the reanalyses are obtained in summer and winter, whereas 


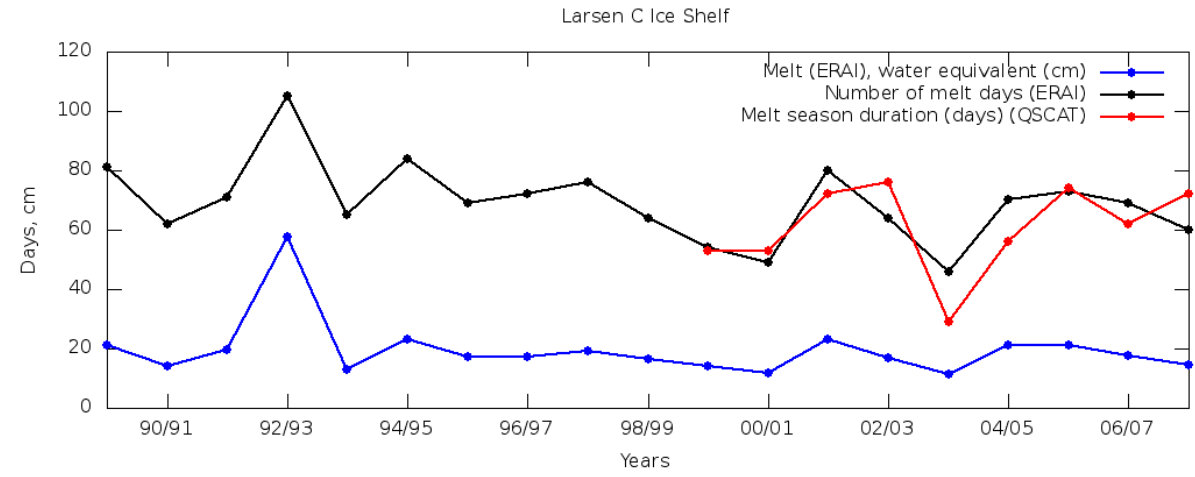

Wilkins Ice Shelf

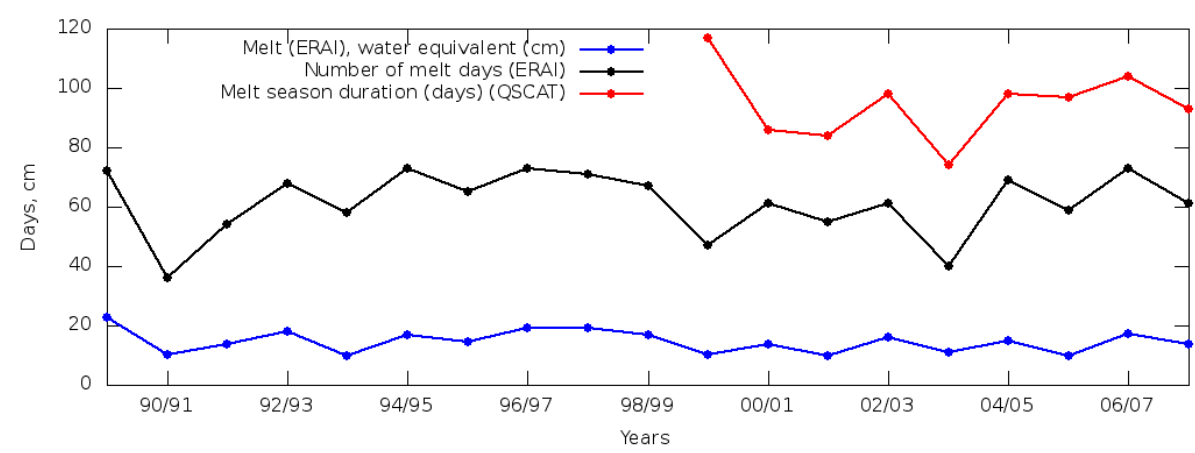

Figure 2. Mean summertime melting and number of melt days on Larsen C and Wilkins ice shelves calculated on the basis of ERAI reanalysis and retrieved from QSCAT observations by Barrand et al. (2013).

in spring and autumn the temperature curves from the three reanalyses overlap. In summer, only ERAI reaches or rises clearly above the melting point on LCIS. On WIS the maximum monthly mean temperature was $1^{\circ} \mathrm{C}$ on both ERAI and JRA reanalyses. While JRA produces almost as warm summers as ERAI, CFSR is 2 to $5^{\circ} \mathrm{C}$ colder every summer than ERAI. In winter, CFSR gives the highest temperatures, i.e. it yields the smallest annual temperature cycle, both on LCIS and WIS. All the three reanalyses give relatively similar variability of the wind components (Fig. 4). JRA shows highest variability in wind, especially in the $U$ component, for which the standard deviation of annual mean is $0.9 \mathrm{~m} \mathrm{~s}^{-1}$ on LCIS and $0.8 \mathrm{~m} \mathrm{~s}^{-1}$ on WIS. JRA also has a stronger V component of the wind on LCIS and weaker one on WIS than ERAI and CFSR. The mean sea level pressure is almost identical in all reanalyses compared, and the pressure variations are similar on LCIS and WIS, the standard deviation of annual mean pressure being around $0.40 \mathrm{hPa}$ higher on WIS than LIS.

\subsection{Trends}

The seasonal mean AWS data exhibited trends in scalar wind speed in all seasons except summer (DJF), but all these trends were negative, indicating a decrease in wind speed on LCIS. The statistically significant trends (95\% level) in autumn, winter and spring were about $-0.02\left(\mathrm{~ms}^{-1} \mathrm{yr}^{-1}\right)$. The annual mean wind speed did not have a trend of any sign. The air temperature and wind components $U$ and $V$ separately at the AWS on LCIS did not show trends in either annual or seasonal means. JRA wind and temperature trends are consistent with the AWS trends, and the trends in wind components in ERAI and CFSR were small, although statistically significant according to the Student's $t$ test (Table 5). On WIS, however, ERAI and JRA showed clear warming trends but in different seasons: ERAI in winter $\left(0.23 \mathrm{Kyr}^{-1}\right)$ and JRA in autumn $\left(0.13 \mathrm{Kyr}^{-1}\right.$, Table 5). There are multiple reasons for the mismatch between observations and reanalyses products. First, the AWS provides only point measurements that cannot be generalised for a larger area. Second, the reanalyses assimilate only limited amount of data from the Antarctic Peninsula region; thus the input data from farther areas might be more dominant in the reanalyses. Third, limitations in modelling and data assimilation might affect the results.

Considering surface fluxes, the annual means included statistically significant trends mostly on WIS, but most of these were so small that they are practically immeasurable (Table 5). For the net heat flux, only CFSR included a minor increasing trend on LCIS.

Several seasonal trends were found (Table 5). In LCIS, ERAI showed seasonal trends in autumn in latent heat flux and net heat flux. ERAI also showed a negative trend in net thermal radiation in DJF. JRA had trends in latent heat flux and net heat flux in LCIS, but in different seasons than ERAI. The trends in latent heat flux were weak and seen in spring 
Larsen C
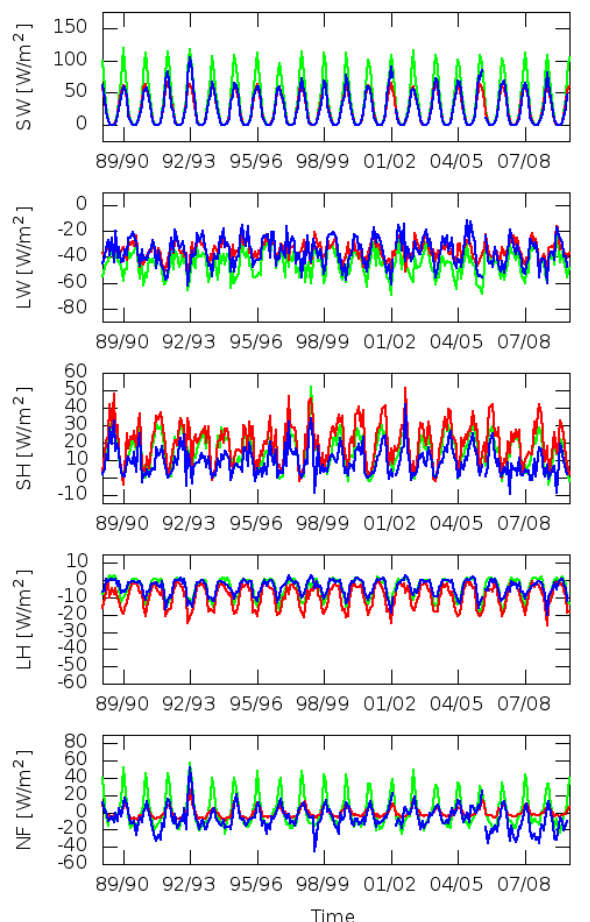

Wilkins
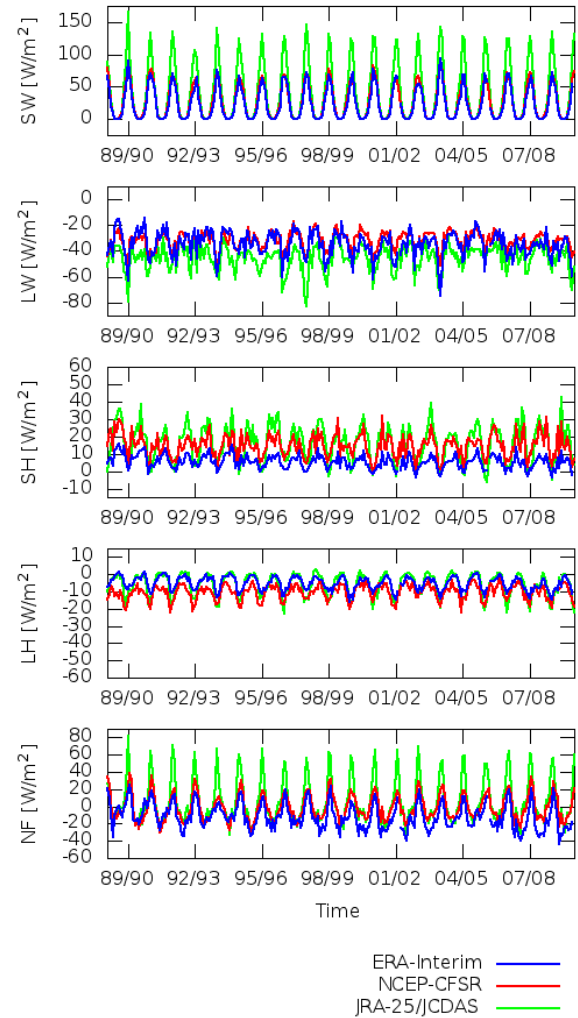

Figure 3. Time series of monthly mean surface energy fluxes on Larsen C and Wilkins ice shelves based on ERAI, CFSR and JRA reanalyses.

Table 5. Statistically significant (95\%) seasonal and annual trends on LCIS during the period from 1989 to 2010 for March, April, May (MAM); June, July, August (JJA); September, October, November (SON); and December, January, February (DJF). Abbreviations are for net longwave radiation (LW), sensible heat flux (SH), latent heat flux $(\mathrm{LH})$, net flux (NF), temperature $2 \mathrm{~m}$ above the surface $(T)$, eastward wind component $(U)$ and northward wind component $(V)$. The units in the table are for the fluxes $\mathrm{Wm}^{-2} \mathrm{yr}^{-1} ;{ }^{\circ} \mathrm{C} \mathrm{yr}^{-1}$ for the temperature and $\left(\mathrm{m} \mathrm{s}^{-1}\right) \mathrm{yr}^{-1}$ for the wind.

\begin{tabular}{lrrrrrr|rrr|rrrr}
\hline & \multicolumn{3}{c}{ ERAI } & & & \multicolumn{3}{c}{ JRA } & \multicolumn{3}{c}{ CFSR } \\
\hline LCIS & LW & SH & LH & NF & $T$ & $V$ & LH & NF & $T$ & LW & LH & NF & $U$ \\
\hline DJF & -0.44 & & & & & & 0.04 & -0.37 & & & & & 0.03 \\
MAM & & & -0.12 & -0.55 & & & & & & & & 0.13 \\
JJA & & & & & & & & & & & & 0.16 \\
SON & & & & & & & -0.07 & & & & & 0.10 \\
Ann. & & & & & & 0.05 & & & & & & 0.10 \\
\hline WIS & LW & SH & LH & NF & $T$ & $V$ & LH & NF & $T$ & LW & LH & NF & $U$ \\
\hline DJF & & -0.15 & -0.10 & & & & 0.22 & & & & & & 0.03 \\
MAM & -0.36 & & -0.16 & -0.55 & & & 0.12 & 0.21 & 0.13 & & & & \\
JJA & -0.41 & -0.27 & -0.09 & -0.78 & 0.23 & & & & & & -0.21 & & \\
SON & & -0.27 & -0.22 & -0.74 & & & & & & & & \\
Ann. & -0.22 & -0.18 & -0.14 & & & & 0.09 & & & 0.17 & -0.10 & & 0.03 \\
\hline
\end{tabular}

and summer. The trend in the net heat flux was observed in summer. In CFSR, on LCIS, the net heat flux had a trend in autumn, winter and spring. All of these show rising net heat flux.
More seasonal trends were found over WIS. As for LCIS, the three reanalyses did not agree regarding the season and magnitude of the trends. One should note in particular that ERAI presented a strong negative trend on the net heat flux in 

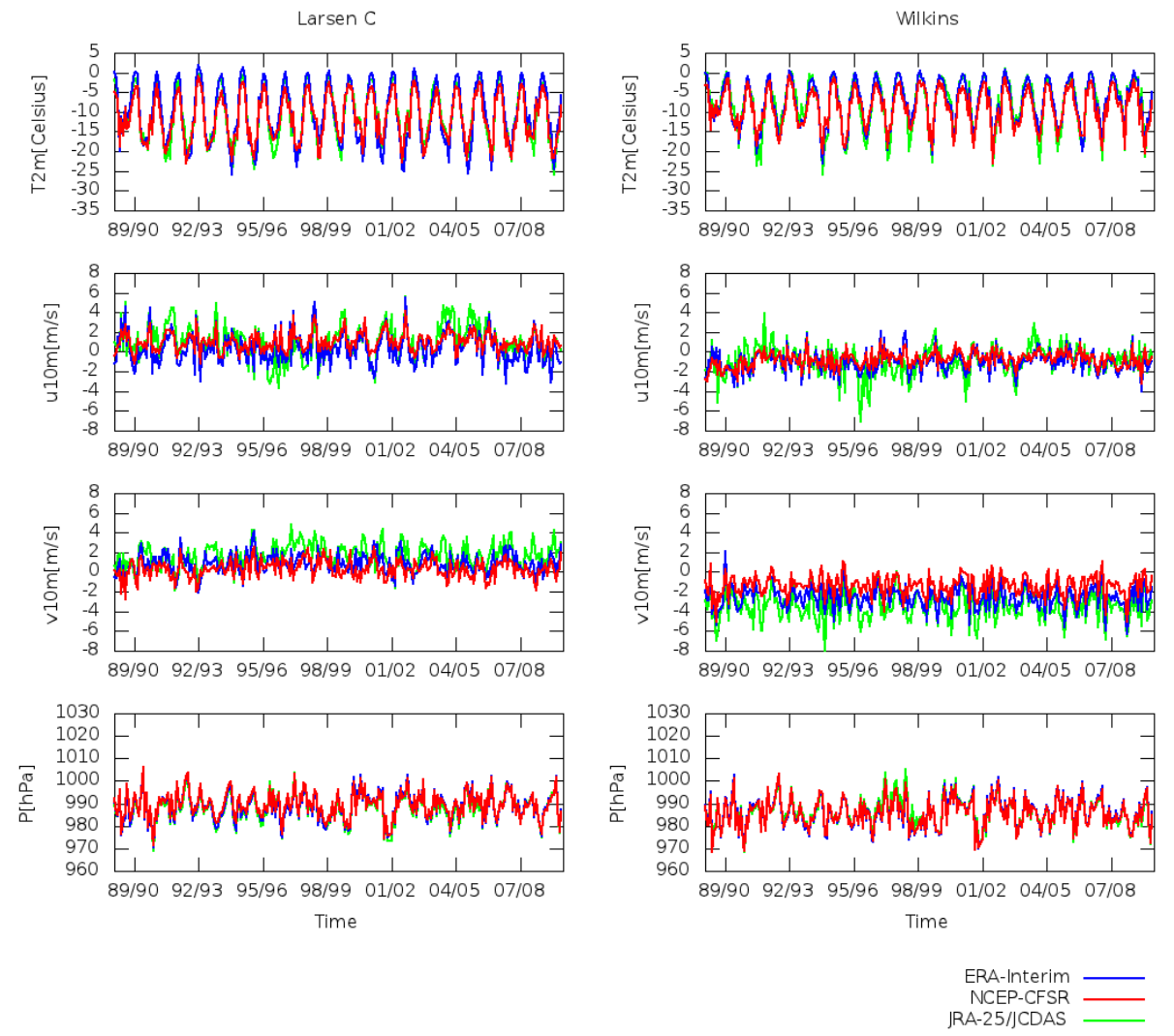

Figure 4. Time series of $2 \mathrm{~m}$ air temperature, $10 \mathrm{~m}$ wind speed and mean sea level pressure on Larsen $\mathrm{C}$ and Wilkins ice shelves on the basis of ERAI, CFSR and JRA reanalyses.

autumn $\left(-0.55 \mathrm{~W} \mathrm{yr}^{-1}\right)$, winter $\left(-0.78 \mathrm{~W} \mathrm{yr}^{-1}\right)$ and spring $\left(-0.74 \mathrm{~W} \mathrm{yr}^{-1}\right)$, which were not present in JRA and CFSR. Instead, JRA had a positive trend in the net heat flux $(0.21$

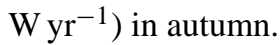

\subsection{Weather conditions favouring large and small surface net fluxes}

As shown in Sect. 3.1, the inter-annual variation in surface net flux is largest in ERAI, whereas CFSR and JRA show very little inter-annual variations in the surface net flux. Large inter-annual variations in the near-surface temperature are common in the Antarctic Peninsula (Vaughan et al., 2003; King, 1994). As the surface temperature is a result of the surface energy balance, the near-surface temperature is also closely connected, through the surface temperature, to the surface energy balance. Thus it can be assumed that the large inter-annual variations in the surface net flux are also typical in the vicinity of Antarctic Peninsula. Hence, the analyses in this section are based on ERAI only. Differences between the years are clearly larger on LCIS than on WIS. On LCIS some austral summers, e.g. 1992/1993, show an exceptionally high net flux and some winters, e.g. 1991 has an exceptionally low surface net flux. Summers with strikingly low, or winters with especially high, surface net flux were not observed.
Next we investigate a summer with high net energy flux and a winter with low energy flux on LCIS. The mean synoptic conditions during these periods are presented and compared to the usual conditions. We have defined the usual condition by calculating the average over the three month summer and winter periods over $20 \mathrm{yr}$ from 1989 to 2010 . We have compared each summer and winter mean separately to the $20 \mathrm{yr}$ mean. Based on this comparison we chose summer 19992000 and winter 1996 as references. We decided to compare the extremes to real climate conditions rather than the $20 \mathrm{yr}$ average condition. The $20 \mathrm{yr}$ seasonal average is an important reference, but the averaged field does not necessarily represent a case that would ever happen in reality.

\subsubsection{Weather conditions favouring a large summertime net heat flux}

Summer 1992-1993 was characterised by an exceptionally high surface net flux on LCIS. In Figs. 5-8, the maps of December-February mean values of sea level pressure, wind speed, cloudiness and surface temperature are presented for summer 1992-1993. For comparison, similar maps are shown also for summer 1999-2000. This reference summer was selected by comparing all summer situations to the 
two-decade mean summer synoptic situation; summer 1999_ 2000 was most similar to the mean situation.

On LCIS the atmospheric pressure was $10 \mathrm{hPa}$ higher in summer 1992-1993 than in summer 1999-2000 (Fig. 5). In summer 1992-1993 the low-pressure minimum was situated on the west side of the peninsula, in the Bellingshausen Sea (the whole low-pressure structure is not visible in Fig. 5 due to the limited area of the map). The pressure increases steadily towards north-east. In summer 1999-2000, a low was situated on the west side of the peninsula, but also another, slightly weaker, low was seen on the east side of the peninsula in the Weddell Sea. The lows were connected by a saddle in the middle part of the peninsula at around 66 to $68^{\circ} \mathrm{S}$. During this summer, the pressure increased rather evenly towards north and south, whereas in summer 19921993 the pressure gradient was in a north-east-south-west direction.

In summer 1992-1993 the winds were predominantly north-westerly (Fig. 6). The wind speed on LCIS was from 2 to $8 \mathrm{~m} \mathrm{~s}^{-1}$, being slightly stronger in the eastern parts of the ice shelf than during the reference summer, 1999-2000. The reference summer was characterised by the lack of seasonal mean northerly wind component on the eastern side of the peninsula. In summer 1999-2000 the seasonal mean wind speed on LCIS was almost uniformly from the west. The cloud coverage on LCIS was eight percentage points higher in 1992-1993 than in 1999-2000 (Table 6, Fig. 7). The increase in cloud fraction coincided with a decrease in downward shortwave radiation and increase in downward longwave radiation (Table 6). As the cloud forcing on net radiation was positive throughout the year (with a minimum of $15 \mathrm{Wm}^{-2}$ in January), the net radiation also increased. Largest differences in the surface skin temperature occurred on the north-eastern coast and south-eastern corner of the peninsula (Fig. 8). On the north-eastern coast the $-2{ }^{\circ} \mathrm{C}$ isotherm moved poleward in summer 1992-1993, so that the major part of LCIS surface was warmer than $-2{ }^{\circ} \mathrm{C}$. In summer 1999-2000, the mean skin temperature of LCIS was between -2 and $-4{ }^{\circ} \mathrm{C}$.

\subsubsection{Weather conditions favouring a small wintertime net heat flux}

During winter 1991 the surface net flux on LCIS was lower than usual. The winter (June, July and August) mean weather conditions in the vicinity on Antarctic Peninsula are presented in Figs. 9-12. Winter 1996 was chosen as a reference on similar grounds to summer 1999-2000 in the summer season comparison.

In winter 1991 a low-pressure centre was situated in the Weddell Sea, whereas in winter 1996 it was situated in the Bellingshausen Sea (Fig. 9). In 1991 the atmospheric pressure on LCIS was about $4 \mathrm{hPa}$ higher than in winter 1996. The pressure gradients over the ice shelf were weak during both winters. In winter 1991, the wind had a predomi- nantly westerly direction with a small southerly component on LCIS, and southerly winds with cold-air advection were dominant further north than in the reference winter (Fig. 10). During the reference winter, the mean wind was from the west with a small northerly component on the western side of the peninsula and southerly component on the eastern side. The wind field on LCIS did not differ much during the two winters.

The cold winter 1991 with a higher atmospheric pressure was related to drier and less cloudy conditions than winter 1996 (Fig. 11). On LCIS, the mean cloud fraction was $68 \%$ in winter 1991 and $78 \%$ in winter 1996 (Table 6). With the lower cloud coverage the incoming longwave radiation was weaker and the net surface radiation lower by $-28 \mathrm{Wm}^{-2}$. In winter 1991 the mean surface skin temperature was lower than in 1996; on LCIS and the Weddell Sea the difference was as much as about $5^{\circ} \mathrm{C}$ (Fig. 12).

\subsubsection{Multiple regression analysis on surface net flux and weather conditions}

Multiple regression analysis was applied to quantitatively investigate how the atmospheric pressure, horizontal wind components, wind speed and cloud fraction affected the surface net heat flux during the whole study period of 19892010. The regression analysis was performed using a stepwise multi-linear regression model. For each season and region the variable to be explained is the surface net energy flux and the possible explanatory variables are mean sea level pressure, $10 \mathrm{~m}$ wind speed, $10 \mathrm{~m}$ wind components and the cloud fraction. The model calculates which combination of explanatory variables yields the best degree of explanation (measured as $R^{2}$ and RMSE) for the surface net energy flux. As possible explanatory variables, we use the abovementioned ones in order to understand how the net flux is controlled by synoptic-scale weather. In some seasons, the analysis yielded statistical relationships with a high degree of explanation (Table 7). The results were better for LCIS than WIS. On LCIS the wind speed, either of the wind components as well as air pressure and cloud fraction together explained 58 to $80 \%$ of the variance of the surface net flux in summer, autumn and winter (in cases when one wind component and wind speed are both included in the equation, we checked that the explaining variables were independent, i.e. had a low mutual correlation). In spring, on neither LCIS nor WIS was the variation in the net flux explained by the weather variables. It is natural that the explaining variables vary seasonally and regionally, as, for example, the cloud cover has different effects on the net heat flux in summer and winter, and the relationships between wind and advection of heat and clouds are different between LCIS and WIS.

By showing statistically significant correlations during the period 1989-2010 between the net heat flux and weather variables, the multiple regression analysis confirms the results based on the extreme summer and winter. In the extreme 

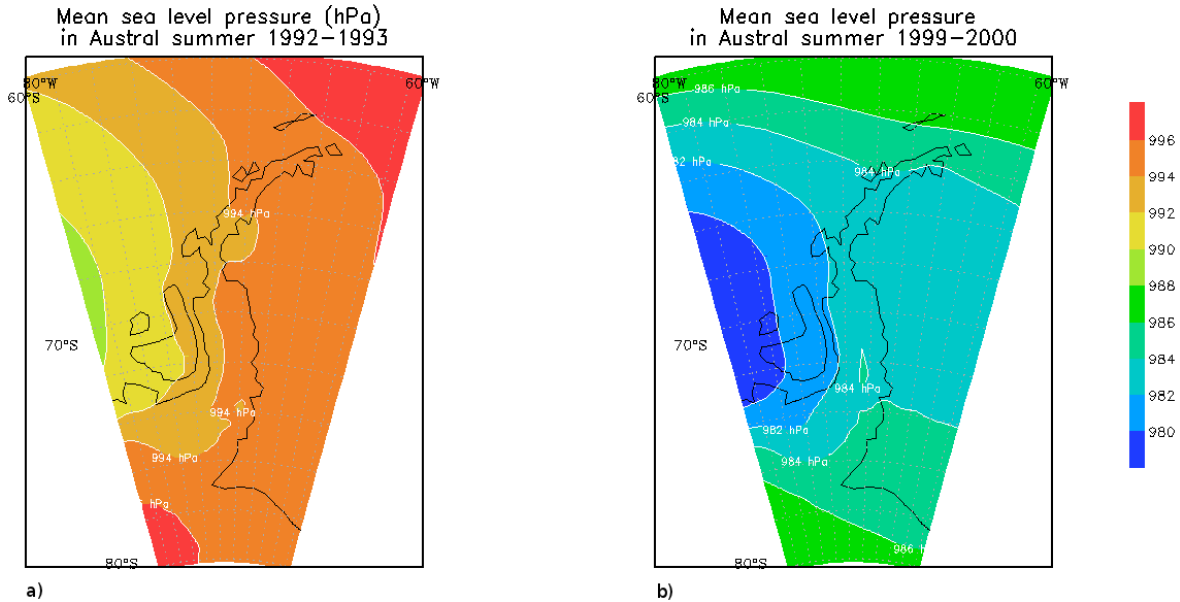

Figure 5. Mean sea level pressure (hPa) in austral summers 1992-1993 (a) and 1999-2000 (b) on the basis of ERAI reanalysis.
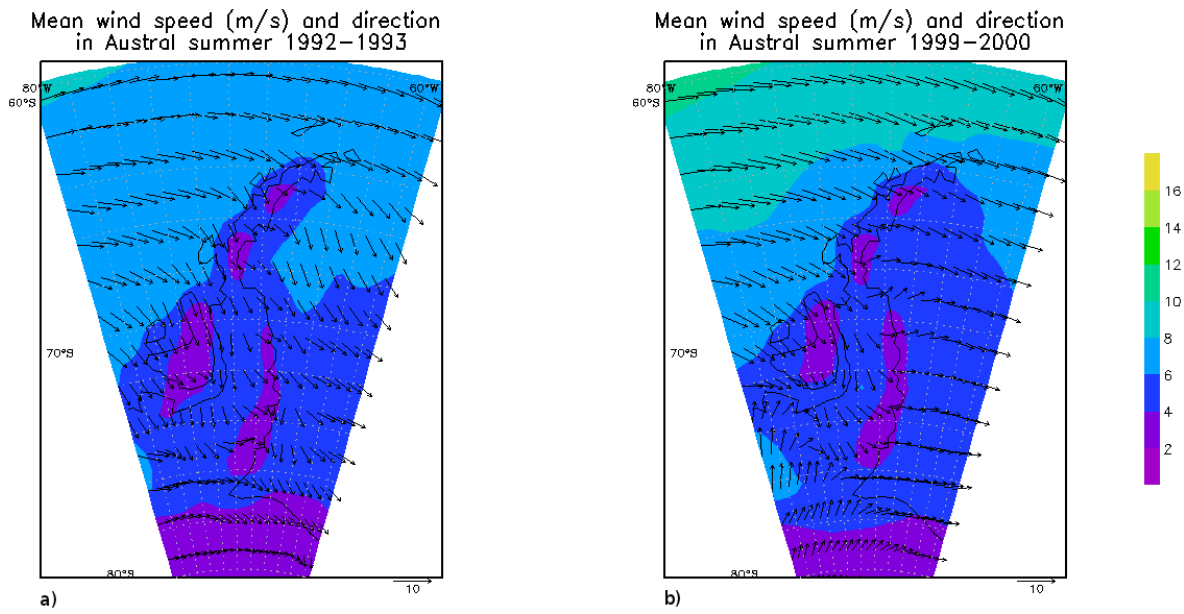

Figure 6. Mean wind speed $\left(\mathrm{m} \mathrm{s}^{-1}\right.$ ) and direction in austral summers 1992-1993 (a) and 1999-2000 (b) on the basis of ERAI reanalysis.

summer of 1992-1993, the large net heat flux over LCIS was favoured by a high atmospheric pressure, winds with a northerly component, and slightly stronger wind speeds (compared to the reference summer, 1999-2000). These features were important not only in summer 1992-1993 but also in the whole summertime data set over LCIS (Table 7). In the extreme winter of 1991, the small net heat flux was favoured by a small cloud fraction, which on the basis of the whole data set was the second-most important factor for a low net heat flux in winter (Table 7). On the basis of the whole data set, however, the lack of strong westerly winds was the most important factor, but westerly winds were present over LCIS in winter 1991. Figures 9 and 10 suggest, however, that the westerlies in winter 1991 were mostly local ones, not related to large-scale advection of warm, moist air masses from the Bellingshausen Sea across the Antarctic Peninsula. This may explain why winter 1991 had such a low net heat flux even though westerly winds dominated over LCIS.

\subsection{Summertime surface melting}

Summertime melting of snow on LCIS and WIS was calculated using the surface temperature and surface fluxes of ERAI. We only applied ERAI because (a) the inter-annual variations in the net flux in the other two reanalyses were very small and (b) the monthly mean surface temperature did not reach the melting point in CFSR, but ranged mostly between -2 and $-4{ }^{\circ} \mathrm{C}$ in every summer. When inter-annual variations are small, they do not catch differences between the years but do produce a rather uniform seasonal cycle for every year. Nevertheless previous studies have indicated that prominent inter-annual variations are typical of the Antarctic Peninsula (King, 1994; Vaughan et al., 2003), which supports the idea that a well-performing reanalysis should produce inter-annual variability too.

Our method to determine the melting resembled that of van den Broeke (2005). The melt calculations were done in $6 \mathrm{~h}$ steps. We used the ERAI surface temperature and 

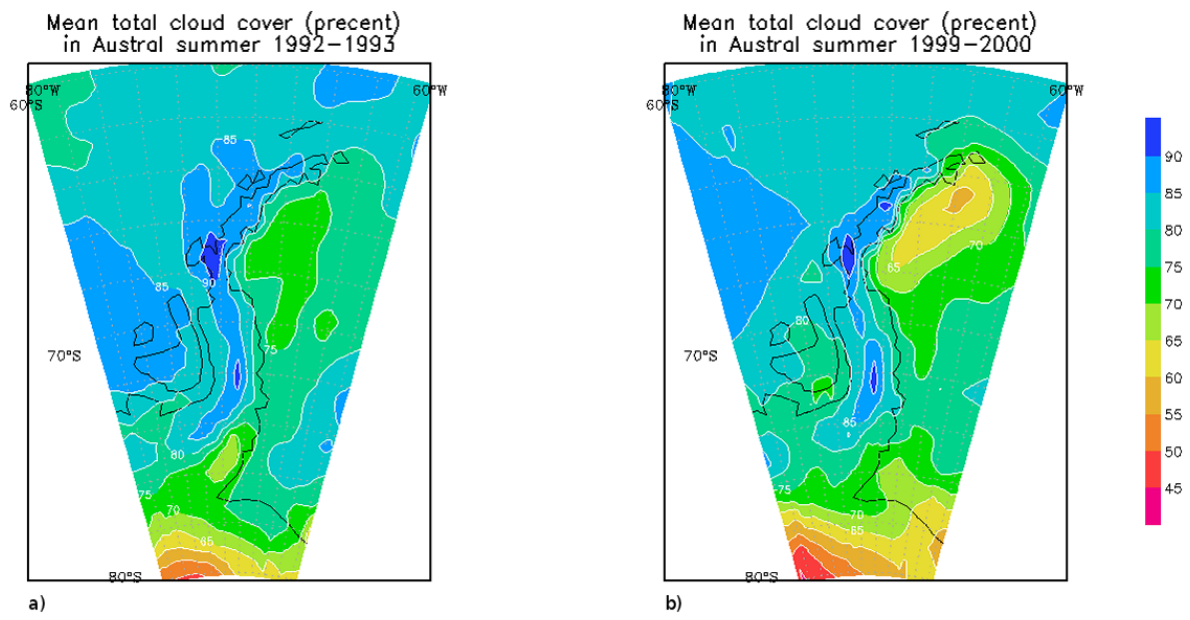

Figure 7. Mean cloud fraction in austral summers 1992-1993 (a) and 1999-2000 (b) on the basis of ERAI reanalysis.
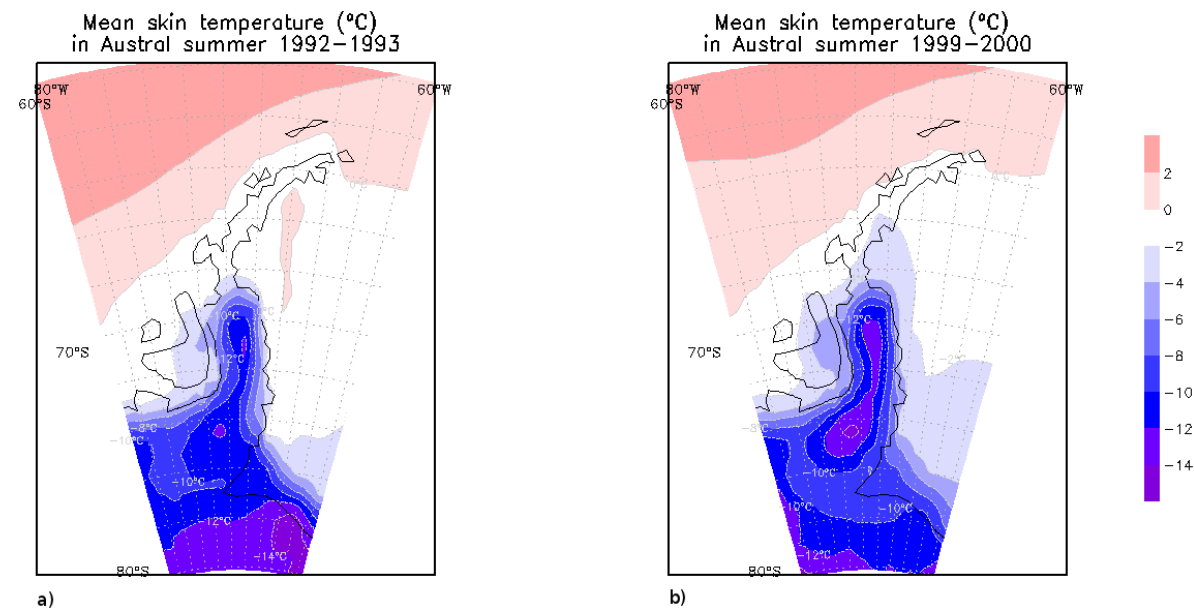

Figure 8. Mean skin temperature in austral summers 1992-1993 (a) and 1999-2000 (b) on the basis of ERAI reanalysis.

calculated the $6 \mathrm{~h}$ mean fluxes from ERAI forecast products. As the starting time steps for the ERAI forecasts are 00:00 and 12:00 UTC, we were able to calculate the $6 \mathrm{~h}$ values for $24 \mathrm{~h}$ periods by using the 6,12 and $18 \mathrm{~h}$ forecasts. In addition to obtaining the $6 \mathrm{~h}$ cumulative values, which were further transformed to $6 \mathrm{~h}$ mean values, we also removed the possible spin-up errors by subtracting the first 6 or $12 \mathrm{~h}$ from the 12 or $18 \mathrm{~h}$ forecasts. The criteria for melting were the following: if the surface temperature at the end of the $6 \mathrm{~h}$ step reached $0^{\circ} \mathrm{C}$, the $6 \mathrm{~h}$ period was considered as a melting period. During these periods, we assumed that the surface net flux was used directly for melting the snow as the surface temperature was already at the melting point. The energy available for melting, $M$, was calculated using

$M=\mathrm{SW}+\mathrm{LW}+\mathrm{SH}+\mathrm{LH}$.

The melt rate is $\mathrm{ML}_{\mathrm{f}}^{-1}$, where $L_{\mathrm{f}}$ is the latent heat of fusion for ice, which can be assumed to be the same for snow (Singh and Singh, 2001). Van den Broeke's (2005) method differed from ours in the following ways: (1) for the temperature that determined melting, he used the air temperature observed at the boom height of an AWS; (2) he applied shortwave radiation calculated from top-of-atmosphere shortwave radiation; (3) he calculated net longwave radiation (LW) following the equation $\mathrm{LW}=0.765 \sigma T^{4}-315.6\left(\mathrm{Wm}^{-2}\right)$ for clear skies and LW $=0$ for overcast condition; (4) he calculated the sensible heat flux without accounting for stability effects on the turbulent heat transfer coefficient; and (5) he ignored the latent heat flux. In our calculations the latent heat flux reduced the summertime melting by over $20 \%$ on both LCIS and WIS.

Both in our calculation and Van Den Broeke's, the ground heat flux has not been taken into account. It is reasonable to ignore the ground heat flux, as during the melt season the snowpack is isothermal at $0{ }^{\circ} \mathrm{C}$ and conductive heat fluxes are small. 
Table 6. Mean cloud fraction (TCC), downward thermal (LWin) and solar radiation (SWin) and net radiation (R_net) on LCIS surface in selected seasons.

\begin{tabular}{lrrrr}
\hline & Winter & Winter & Summer & Summer \\
& 1991 & 1996 & $1992-1993$ & $1999-2000$ \\
\hline TCC $(\%)$ & 68 & 78 & 75 & 67 \\
LWin $\left(\mathrm{Wm}^{-2}\right)$ & 196 & 213 & 271 & 257 \\
SWin $\left(\mathrm{Wm}^{-2}\right)$ & 5 & 4 & 242 & 273 \\
R_net $\left(\mathrm{Wm}^{-2}\right)$ & -42 & -27 & 41 & 13 \\
\hline
\end{tabular}
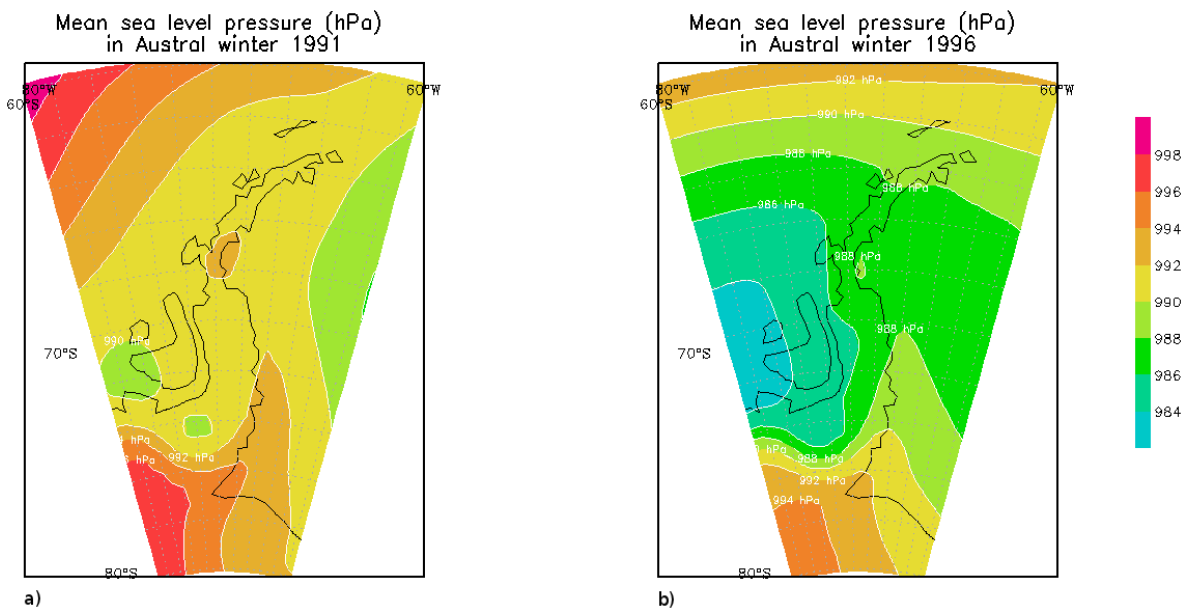

Figure 9. Mean sea level pressure in austral winters 1991 (a) and 1996 (b) on the basis of ERAI reanalysis.

Our calculations for LCIS yielded 46-105 melt days per summer, and the melt during a summer ranged from 11 to $58 \mathrm{~cm}$ water equivalent (w.e.), the mean melt being $19 \mathrm{~cm}$ w.e. (Fig. 2). The value on LCIS compares well with that of about $20 \mathrm{~cm}\left(8.7 \mathrm{Wm}^{-2}\right)$ measured by Kuipers Munneke et al. (2012) in 2009-2011. For WIS we obtained 36-73 melt days per summer and the melt varied from 10 to $23 \mathrm{~cm}$ w.e. (mean of $15 \mathrm{~cm}$ w.e.) per summer. The most striking feature in the time series is the strong melt in summer 1992-1993 on LCIS (Fig. 2).

Unfortunately the Larsen C AWS was out of commission in summer 1992-1993, and thus could not be used for confirming the peaking of melt during that summer. During summers 1989-1990 and 1994-1995, which are identifiable by the high number of melt days on LCIS, the monthly mean temperature was above $0^{\circ} \mathrm{C}$ during one summer month according to the AWS. Monthly mean temperatures did not rise above freezing point during any other period between 1989 and 2010. According to the AWS data, summer 2002-2003, which experienced a large melt, was not distinctly warmer than other summers.

\section{Discussion and conclusions}

A hindering aspect in the studies of the changing climate over Antarctic ice shelves is the lack of observations and the brevity of the existing data sets. In particular, there are no long time series on surface fluxes over LCIS and WIS. Hence, this study was mostly based on atmospheric reanalyses, which have weaknesses in high latitudes. Our study revealed significant differences between ERAI, CFSR and JRA on LCIS and WIS.

According to our knowledge, near-surface variables of reanalyses have not been previously validated over Antarctic Peninsula ice shelves, as previous validation studies of atmospheric reanalyses in the Antarctic have mostly focused on large-scale features, such as cyclones (Hodges et al., 2011) and precipitation (Bromwich et al., 2011). We aspired to validate the reanalyses both on the western and eastern side of the peninsula, but due to better availability of in situ observations, the validation is more thorough on LCIS than WIS. The validation against the AWS observations on LCIS demonstrated that ERAI can reasonably well reproduce the observed inter-annual variations of seasonal mean air temperature for winter, spring and summer, whereas CFSR is good for summer and spring, and JRA for summer. For the wind components, the correlations were lower on average. We note, however, that AWS observations are also liable to 

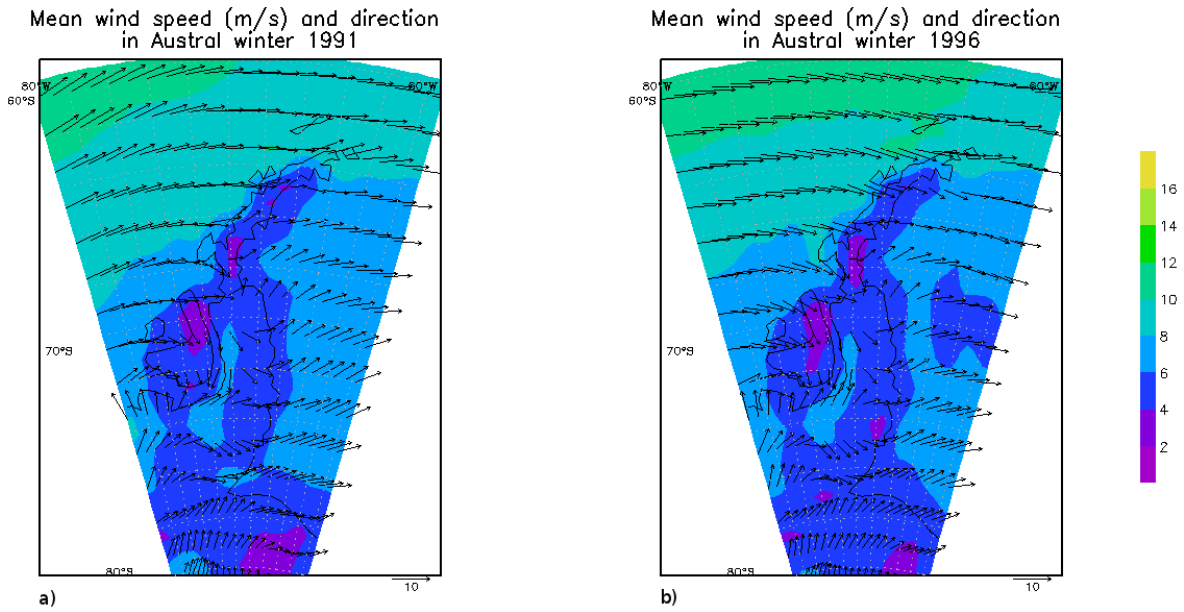

Figure 10. Mean wind speed and direction in winters 1991 (a) and 1996 (b) on the basis of ERAI reanalysis.
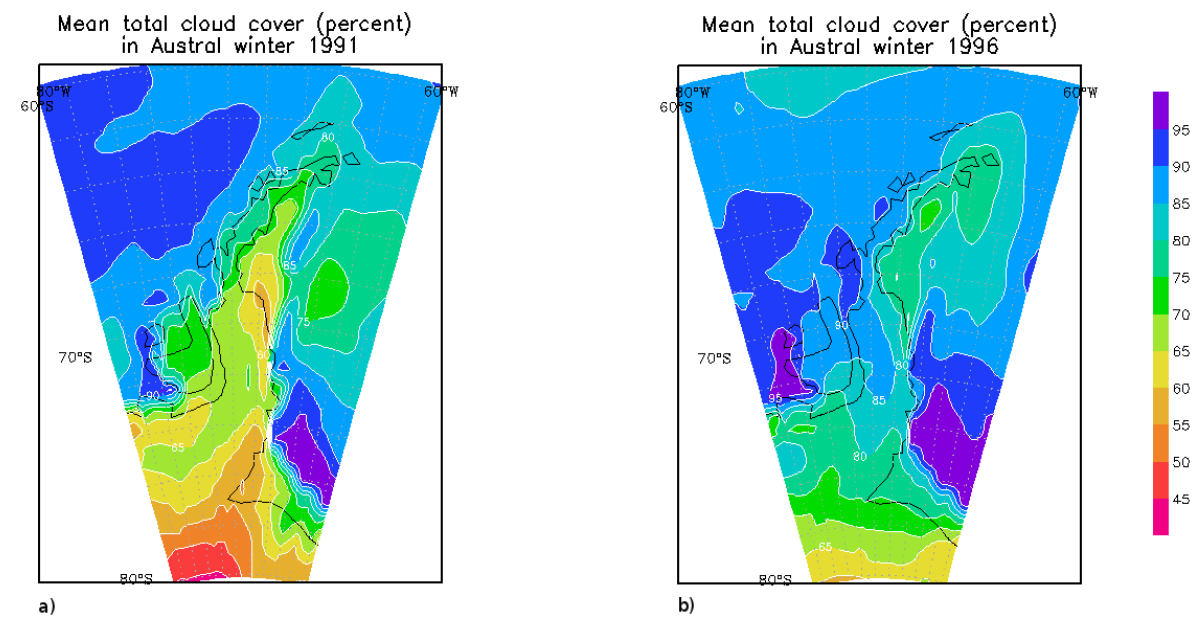

Figure 11. Mean cloud fraction in austral winters 1991 (a) and 1996 (b) on the basis of ERAI reanalysis.

errors, which may have lowered the correlation coefficients. Focusing on biases of seasonal means, our validation results include three interesting issues: (1) all three reanalyses had warm temperature biases in all seasons, (2) all three reanalyses yielded positive biases for the eastward wind component in all seasons, and (3) reanalyses mostly yielded negative biases for the northward wind component. The first issue is in agreement with many previous validation studies over snow and ice surfaces: Jakobson et al. (2012) obtained similar results for the same (and other) reanalyses over the Arctic sea ice, Vihma et al. (2002) observed a year-round warm bias for the ECMWF operational analyses over the Antarctic sea ice, and Atlaskin and Vihma (2012) observed that several numerical weather prediction models yielded warm biases under conditions of stable boundary layer over snowcovered boreal forest. The second and third issue are probably at least partly due to the resolution of reanalyses, which is not high enough to accurately represent the complex orogra- phy of the Antarctic Peninsula. This results in overestimation of westerly winds blowing over the peninsula (Stössel et al., 2011), and these strong westerlies and reduced generation of barrier winds result in an underestimation of the northward wind component. This also means that the reanalyses will not properly represent the formation of föhn winds on the eastern side of the peninsula, which are believed to be important in promoting melt on LCIS (Marshall et al., 2006).

Also, the comparison of the three reanalyses over LCIS and WIS yielded interesting results. The time series of the mean sea level pressure were almost identical in the three reanalyses, both on LCIS and WIS. The monthly mean sea level pressure also had consistent variation on both sides of the peninsula. However, the summertime $2 \mathrm{~m}$ air temperature on LCIS differed remarkably between ERAI and CFSR. ERAI reached the melting point every summer, whereas the summer temperatures of CFSR were typically from -4 to $-2{ }^{\circ} \mathrm{C}$. The ERAI mean wind speeds were about $3 \mathrm{~m} \mathrm{~s}^{-1}$ 

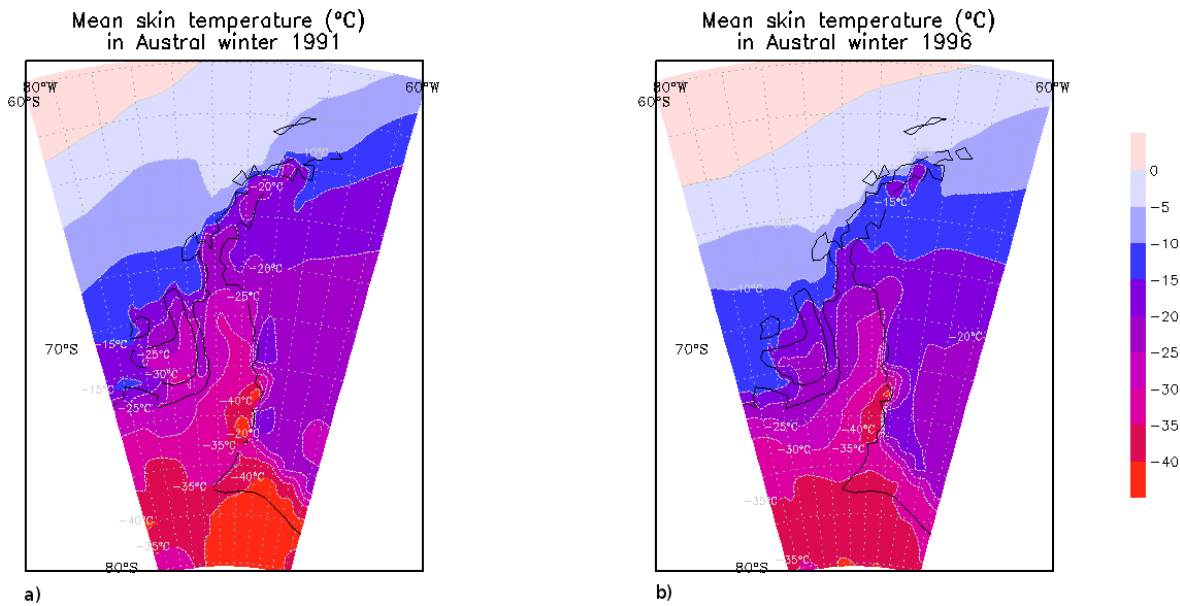

Figure 12. Mean skin temperature in winters 1991 (a) and 1996 (b) on the basis of ERAI reanalysis.

Table 7. Multiple regression equations and explanation levels for surface net flux (NF) explained by weather variables: mean sea level air pressure $(p$, in $\mathrm{hPa}), 10 \mathrm{~m}$ wind speed ( $\mathrm{UV}$, in $\mathrm{m} \mathrm{s}^{-1}$ ), eastward wind component $(U)$, northward wind component $(V)$ and the cloud fraction $(N, 0-1)$.

\begin{tabular}{lllrr}
\hline Region & Period & Multiple regression equation & $r^{2}$ & RMSE \\
\hline Larsen C & DJF & $\mathrm{NF}=-5.5 V+8.4 \mathrm{UV}+0.6 p-626$ & 0.79 & 3.2 \\
Larsen C & MAM & $\mathrm{NF}=3.4 V+0.6 p-3.6 \mathrm{UV}-104$ & 0.58 & 5.0 \\
Larsen C & JJA & $\mathrm{NF}=9.2 U+158.5 N+1.0 p-5.6 \mathrm{UV}-1126$ & 0.80 & 4.5 \\
Wilkins & MAM & $\mathrm{NF}=3.0 U-18$ & 0.26 & 4.5 \\
Wilkins & JJA & $\mathrm{NF}=79.9 N-88$ & 0.27 & 7.0 \\
\hline
\end{tabular}

higher than those of CFSR. JRA had very different wind speed variations than ERAI and CFSR, both on LCIS and WIS. The most striking differences in surface fluxes were related to the very large solar radiation in JRA on WIS.

In general, ERAI had larger inter-annual variations compared to the almost uniform years in CFSR. This suggests that the patterns in ERAI are more realistic, considering the observations on large inter-annual variability in the peninsula region (King, 1994; Vaughan et al., 2003). Although ERAI has a much coarser horizontal resolution $(79 \mathrm{~km})$ than CFSR $(38 \mathrm{~km})$, it has the clear advantage of applying the 4D-VAR data assimilation, which is not used in CFSR and JRA. Although JRA performed poorly in the temperature validation, it was the best reanalysis for the zonal wind component. In the Arctic, Jakobson et al. (2012) noticed the good quality of JRA winds. In general, taking into account the inter-annual variation and the performance, ERAI was found to be the most appropriate reanalysis for more specific studies of the weather patterns.

When the summertime surface net heat flux on LCIS was exceptionally high (1992-1993), the mean sea level pressure in the vicinity of the peninsula was higher than general, and the pressure difference between the east and the west side of the peninsula was greater. Due to the anomalous pressure field, the surface winds were from north-west on the eastern side of the peninsula. The warm-air advection together with large downward longwave radiation under extensive cloud cover contributed to the high air and snow surface temperatures on LCIS. Also, previous studies have indicated that high temperatures on Larsen Ice Shelf were found together with north-westerly winds (Kuipers Munneke et al., 2012) and the breakup of Larsen B Ice Shelf in 2002 was preceded by northwesterly winds (van den Broeke, 2005). During the winter with anomalously small surface net energy flux, the mean sea level pressure was higher than during the winters when the surface net flux was close to the long term average. This tends to reduce the cloud cover, which results in weaker cloud radiative forcing, allowing the surface to cool more. During the winter of low surface net flux (1991), the pressure field was also significantly different from regular winters and summers. The lowest pressures were situated in the Weddell Sea, forcing the southerly winds in the vicinity of the peninsula. The surface temperatures were lower, likely due to cold-air advection and strong radiative cooling.

The climate warming in the peninsula region (e.g. King, 1994; Vaughan et al., 2003) was not as clearly present in our results as could have been expected. The AWS observations on LCIS did not include any significant temperature trend, and the reanalyses showed warming trends only over WIS: ERAI in winter $\left(0.23^{\circ} \mathrm{C} \mathrm{yr}^{-1}\right)$ and JRA in autumn 
$\left(0.13^{\circ} \mathrm{Cyr}^{-1}\right)$. Also, according to previous assumptions on the climate evolution in the peninsula region (e.g. Kuipers Munneke, 2012), trends on wind would have been expected. Among reanalyses, only CFSR showed trends: in the eastward component in summer on LCIS $\left(+0.03 \mathrm{~ms}^{-1} \mathrm{yr}^{-1}\right)$ and WIS $\left(+0.03 \mathrm{~ms}^{-1} \mathrm{yr}^{-1}\right)$.

Our calculations for LCIS yielded 46 to 105 melt days per summer. Van den Broeke (2005) estimated from 50 to 100 melt days per summer for the same area. Comparing the same period as van den Broeke (2005), from 1995 to 2003, our result for the average number of melt days was 68 per summer, whereas that of van den Broeke was 69. For the same period, we calculated the summer melt to range from 11 to $23 \mathrm{~cm}$, whereas van den Broeke got 10 to $42 \mathrm{~cm}$. The differences are likely related to the five differences in the calculation methods (Sect. 3.4). One of them was that we defined the melting according to the ERAI surface temperatures, whereas van den Broeke used the air temperature measured at the boom height $(3 \mathrm{~m})$ of the AWS. Also, ignoring the latent heat flux may have yielded to overestimation of melting in van den Broeke (2005). We note that neither we nor van den Broeke (2005) took into account the absorption of solar radiation into the snow. The penetration of shortwave radiation into the snow changes the partitioning between surface and subsurface melt, and increases the total melt (Cheng et al., 2008; Kuipers Munneke et al., 2012).

Van den Broeke stated that melting in summer 2001-2002 was exceptionally strong on LCIS. We did not observe the same, but instead noted increased melting in 2002-2003. Outside of van den Broeke's study period, summer 19921993 stands out with strong melting on both LCIS and WIS. The final disintegrations of Larsen A and Prince Gustav ice shelves happened in early 1995 (Rott et al., 1996; Cooper, 1997; Cook and Vaughan, 2010) following the record high melt in 1992-1993. On WIS the peak values in melting in summers, based on our calculations, seem to agree with the major collapses in 1990-1991, 1993, 1998 and 2003-2004 (Braun et al., 2009). Nevertheless, a major collapse occurred also in 2008, when the melting was modest, and in 2006 the area of WIS did not change much in spite of the strong melting.

To determine the uncertainty of our melt estimate, we validated the weather variables and radiative fluxes during the melt periods in year 2009, when both weather and radiation observations were available on LCSI. This validation showed a positive bias of $21 \mathrm{Wm}^{-2}$ for the net radiation. Biases for both incoming and outgoing longwave radiation were about $-7.5 \mathrm{Wm}^{-2}$, meaning correct net longwave radiation. The bias in wind component was about $-0.5 \mathrm{~m} \mathrm{~s}^{-1}$ and $5.6 \mathrm{~K}$ in the temperature. Positive biases in net radiation and temperature indicate a possible overestimation in our melt. The negative bias in wind indicates too weak turbulent heat exchange, which would also lead to overestimation of melt. We have to note that, over a longer period, the temperature bias during melting was smaller, indicating a smaller overall error in the melt estimate. To obtain an error estimate of melting on WIS, we have to rely on satellite observations presented by Barrand et al. (2013). The satellite data suggest that calculations based on ERAI fluxes significantly underestimate the melting on WIS. The satellite melt observations also provide a better match with the progressive disintegration of WIS. On LCIS the melt values by Barrand et al. (2013) and our melt calculations based on ERAI matched each other very closely.

We conclude that atmospheric reanalyses provide useful information on the surface energy budget and melt of Antarctic ice shelves, on inter-annual variations in the budget terms, and on the weather conditions associated with high and low net heat flux to the ice shelves. Care should, however, be taken when making conclusions on the basis of reanalysis products; in our case the validation and comparison of three reanalyses were essential. As a whole, our results support the idea that the recent disintegrations of Larsen ice shelves and WIS are partly of atmospheric origin. As the next step, we consider it important to carry out more detailed melt calculations applying a thermodynamic snow model, forced by atmospheric reanalyses, that accounts for the role of subsurface melting.

Acknowledgements. This study was supported by the Academy of Finland through the AMICO project (contracts 128533 and 263918). ECMWF, JMA and NCEP are acknowledged for providing us with the reanalysis products. The automatic weather station measurements were funded by the UK Natural Environment Research Council as part of the British Antarctic Survey's core programme "Polar Science for Planet Earth". We would like to thank N. E. Barrand (University of Birmingham, UK) for providing us satellite-based melt calculations over Larsen and Wilkins ice shelves. J. C. King acknowledges support from NERC under grant no. NE/G014124/1 "Orographic Flows and the Climate of the Antarctic Peninsula". This publication is contribution number 19 of the Nordic Centre of Excellence SVALI, "Stability and Variations of Arctic Land Ice", funded by the Nordic Top-level Research Initiative (TRI).

Edited by: E. Hanna

\section{References}

Atlaskin, E. and Vihma, T.: Evaluation of NWP results for wintertime nocturnal boundary-layer temperatures over Europe and Finland, Q. J. Roy. Meteor. Soc., 138, 1440-1451, 2012.

Barrand, N. E., Vaughan, D. G., Steiner, N., Tedesco, M., Kuipers Munneke, P., van den Broeke, M. R., and Hosking, J. S.: Trends in Antarctic Peninsula surface melting conditions from observations and regional climate modeling, J. Geophys. Res., 118, 116, doi:10.1029/2012JF002559, 2013.

Bengtsson, L., Arkin, P., Berrisford, P., Bougeault, P., Folland, C. K., Gordon, C., Haines, K.,Hodges, K. I., Jones, P., Kållberg, P., Raynes, N., Simmons, A. J., Stammer, D., Thorne, P. W., Uppala, S., and Vose, R. S.: The need for a dynamical climate reanalysis, B. Am. Meteorol. Soc., 88, 495-501, 2007. 
Braun, M., Humbert, A., and Moll, A.: Changes of Wilkins Ice Shelf over the past 15 years and inferences on its stability, The Cryosphere, 3, 41-56, doi:10.5194/tc-3-41-2009, 2009.

Bromwich, D. H., Nicolas, J. P., and Monaghan, A. J.: An assessment of precipitation changes over Antarctica and the Southern Ocean since 1989 in contemporary global reanalyses, J. Climate, 1406, 1-62, 2011.

Chapman, L. W. and Walsh, J. E.: A synthesis of Antarctic temperatures, J. Climate, 20, 4096-4117, 2007.

Cheng, B., Zhang, Z., Vihma, T., Johansson, M., Bian, L., Li, Z., and $\mathrm{Wu}, \mathrm{H}$.: Model experiments on snow and ice thermodynamics in the Arctic Ocean with CHINARE 2003 data, J. Geophys. Res., 113, 1-15, 2008.

Collins, W. D., Bitz, C., Boville, B. A., Briegled, B., Dai, Y., Hack, J. J., Kiehl, J. T., Lin, S.-J., Mccaa, J. R., Rasch, P. J., Rood, R. B., Williamson, D. L., and Zhang, M.: Description of the NCAR Community Atmosphere Model (CAM2), available at: http://www.ccsm.ucar.edu/models/atm-cam/docs/cam2. 0/description/index.html (last access: 23 April 2013), 2002.

Comiso, J. C.: Variability and trends in Antarctic surface temperatures from in situ and satellite infrared measurements, J. Climate, 13, 1674-1696, 2000.

Cook, A. J. and Vaughan, D. G.: Overview of areal changes of the ice shelves on the Antarctic Peninsula over the past 50 years, The Cryosphere, 4, 77-98, doi:10.5194/tc-4-77-2010, 2010.

Cooper, A. P. R.: Historical observations of Prince Gustav Ice Shelf, Polar Rec., 33, 285-294, 1997.

Cullather, R. I. and Bosilowich, M. G.: The energy budget of the Polar atmosphere in MERRA, J. Climate, 25, 5-24, 2012.

De Angelis, H. and Skvarca, P: Glacier surge after ice shelf collapse, Science, 299, 1560-1562, 2003.

Dee, D., Uppala, S. M., Simmons, A. J., Berrisford, P., Poli, P., Kobayashi, S., Andrae, U., Balmaseda, M. A., Balsamo, G., Bauer, P., Bechtold, P., Beljaars., A. C. M., van de Berg, L., Bidlot, J., Bormann, N., Delsol, C., Dragani, R., Fuentes., M., Geer, A. J., Haimberger, L., Healy, S. B., Hersbach, H., Holm, E. V., Isaksen, L., Kållberg, P., Köhler, M., Matricardi, M., McNally, A. P., Monge-Sanz, B. M., Morcrette, J.-J., Park, B.-K., Peubey, C., de Rosnay, P., Tavolato, C., Thépaut, J.-N., and Vitart, F.: The ERA-Interim reanalysis: configuration and performance of the data assimilation system, Q. J. R. Meteor. Soc., 137, 553-597, 2011

Depoorter, M. A., Bamber, J. L., Griggs, J. A., Lenaerts, J. T. M., Ligtenberg, S. R. M., van den Broeke, M. R., and Moholdt, G.: Calving fluxes and basal melt rates of Antarctic ice shelves, Nature, 502, 89-92, doi:10.1038/nature12567, 2013.

Early, D. and Long, D.: Image reconstruction and enchanced resolution imaging from irregular samples, IEEE T. Geosci. Remote, 39, 291-302, 2001.

ECMWF: IFS documentation CY31r1, available at: http://www. ecmwf.int/research/ifsdocs/CY31r1/index.html (last access: 18 October 2011), 2007.

Glasser, N. F. and Scambos, T. A.: A structural glaciological analysis of the 2002 Larsen B ice shelf collapse, J. Glaciol., 54, 3-16, 2008.

Glasser, N. F., Kulessa, B., Luckman, A., Jansen, D., King, E. C., Sammond, P. R., Scambos, T. A., and Jezek, K. C.: Surface structure and stability of the Larsen C ice shelf, Antarctic Peninsula, J. Glaciol., 55, 400-410, 2009.
Hodges, K. I., Lee, R. W., and Bengtsson, L.: A comparison of extra-tropical cyclones in recent re-analyses; ERA-INTERIM, NASA-MERRA, NCEP-CFSR and JRA25, J. Climate, 24, 4888-4906, 2011.

Jakobson, E., Vihma, T., Palo, T., Jakobson, L., Keernik, H., and Jaagus, J.: Validation of atmospheric reanalyses over the central Arctic Ocean, Geophys. Res. Lett., 39, 1-6, 2012.

Jansen, D., Kulessa, B., Sammonds, P. R., Luckman, A., King, J. C., and Glasser, N. F.: Present stability of the Larsen C ice shelf, Antarctic Peninsula, J. Glaciol., 56, 593-600, 2010.

King, J. C.: Recent climate variability in the vicinity of the Antarctic Peninsula, Int. J. Climatol., 14, 357-369, 1994.

King, J. C. and Turner, J.: Antarctic Meteorology and Climatology, Cambridge University Press, Cambridge, United Kingdom, 1997.

Kuipers Munneke, P., van den Broeke, M. R., King, J. C., Gray, T., and Reijmer, C. H.: Near-surface climate and surface energy budget of Larsen C ice shelf, Antarctic Peninsula, The Cryosphere, 6, 353-363, doi:10.5194/tc-6-353-2012, 2012.

Long, D. and Hicks, B.: Standard BYU QuikSCAT and Seawinds land/ice image products, revision 3.1, technical report, Brigham Young Univ., Provo, Utah, 2010.

Marshall, G. J., Orr, A., van Lipzig, N. P. M, and King, J. C.: The impact of a changing Southern Hemisphere annular mode on Antarctic Peninsula summer temperatures, J. Climate, 19, 53885404, 2006.

Mercer, J. H.: West Antarctic Ice Sheet and $\mathrm{CO}_{2}$ greenhouse effect: a threat of disaster, Nature, 271, 321-325, 1978.

Morris, E. M. and Vaughan, D. G.: Spatial and temporal variation of surface temperature on the Antarctic Peninsula and the limit of viability of ice shelves, Antarct. Res. Ser., 79, 61-68, 2003.

Onogi, K., Tsutsui, J., Koide, H., Sakamoto, M., Kobayashi, S., Hatsushika, H., Matsumoto, T., Yamazaki, N., Kamahori, H., Takahashi, K., Kadokura, S., Wada, K., Kato, K., Oyama, R., Ose, T., Mannoji, N., and Taira, R.: The JRA-25 Reanalysis, J. Meteorol. Soc. Jpn., 85, 369-432, 2007.

Orr, A., Cresswell, D., Marshall, G. J., Hunt, J. C. R., Sommeria, J., Wang, C. G., and Light, M.: A "low-level" explanation for the recent large warming trend over the western Antarctic Peninsula involving blocked winds and changes in zonal circulation, Geophys. Res. Lett., 31, L06204, doi:10.1029/2003GL019160, 2004

Pirazzini, R.: Challenges in Snow and Ice Albedo Parametrizations, Geophysica, 45, 41-62, 2009.

Rienecker, M. M., Suarez, M. J., Gelaro, R., Todling, R., Bacmeister, J., Liu, E., Bosilovich, M. G., Schubert, S. D., Takacs, L., Kim, G.-K., Bloom, S., Chen, J., Collins, D., Conaty, A., Da Silva, A., Gu, W., Joiner, J., Koster, R. D., Lucchesi., R., Molod, A., Owens, T., Pawson, S., Pegion, P., Redder, C. R., Reichle, R., Robertson, F. R., Ruddick, A. G., Sienkiewicz, M., and Woollen, J.: MERRA: NASA's Moder-Era Retrospective Analysis for Research and Applications, J. Climate, 24, 3624-3648, doi:10.1175/JCLI-D-11-00015.1, 2011.

Rignot, E., Casassa, G., Gogineni, P., Krabill, W., Rivera, A., and Thomas, R.: Accelerated ice discharge from the Antarctic Peninsula following the collapse of Larsen B ice shelf, Geophys. Res. Lett., 31, L18401, doi:10.1029/2004GL020697, 2004.

Rott, H., Skvarca, P., and Nagler, T.: Rapid collapse of northern Larsen Ice Shelf, Antarctica, Science, 271, 788-792, 1996. 
Rott, H., Rack, W., Nagler, T., and Skvarca, P.: Climatically induced retreat and collapse of northern Larsen Ice Shelf, Antarctic Peninsula, Ann. Glaciol., 27, 86-92, 1998.

Rott, H., Rack, W., Skvarca, P., and De Angelis, H.: Northern Larsen Ice Shelf, Antarctica: further retreat and collapse, Ann. Glaciol., 34, 277-282, 2002.

Rott, H., Müller, F., Nagler, T., and Floricioiu, D.: The imbalance of glaciers after disintegration of Larsen-B ice shelf, Antarctic Peninsula, The Cryosphere, 5, 125-134, doi:10.5194/tc-5-1252011, 2011.

Saha, S., Moorthi, S., Pan, H.-L., Wu, X., Wang, J., Nadiga, S., Tripp, P., Kistler, R., Woollen, J., Behringer, D., Liu, H., Stokes, D., Grumbine, R., Gayno, G., Wang, J., Hou, Y.-T., Chuang, H.Y., Juang, H.-M. H., Sela, J., Iredell, M., Treadon, R., Kleist, D., Van Delst, P., Keyser, D., Derber, J., Ek, M., Meng, J., Wei, H., Yang, R., Lord, S., van den Dool, H., Kumar, A., Wang, W., Long, C., Chelliah, M., Xue, Y., Huang, B., Schemm, J.-K., Ebisuzaki, W., Lin, R., Xie, P., Chen, M., Zhou, S., Higgins, W., Zou, C.-Z., Liu, Q., Chen, Y., Han, Y., Cucurull, L., Reynolds, R. W., Rutledge, G., and Goldberg, M.: The NCEP Climate Forecast System Reanalysis, B. Am. Meteorol. Soc., 91, 1015-1057, 2010.

Sansom, J.: Antarctic surface temperature time series, J. Climate, 2, 1168-1172, 1989.

Scambos, T. A., Hulbe, C., Fahnestock, M., and Bohlander, J.: The link between climate warming and break-up of ice shelves in the Antarctic Peninsula, J. Glaciol., 46, 516-530, 2000.

Scambos, T. A., Hulbe, C., and Fahnestock, M.: Climate induced ice shelf disintegration in the Antarctic Peninsula, Antarct. Res. Ser., 76, 335-347, 2003.

Sellers, P. J., Mintz, Y., Sud, Y. C., and Dalcher, A.: A Simple Biosphere Model ( $\mathrm{SiB})$ for Use within General Circulation Models, J. Atmos. Sci., 43, 505-531, 1986.

Shepherd, A., Wingham, D., Payne, T., and Skvarca, P.: Larsen Ice Shelf has progressively thinned, Science, 302, 856-859, 2003.

Singh, P. and Singh, V. P.: Snow and Glacier Hydrology, Kulwer Academic Publisher, Dordrech, the Netherlands, 2001.

Stössel, A., Zhang, Z., and Vihma, T.: The effect of alternative realtime wind forcing on Southern Ocean sea ice simulations, J. Geophys. Res., 116, C11021, doi:10.1029/2011JC007328, 2011.
Tastula, E.-M., Vihma, T., Andreas, E. L., and Galperin, B.: Validation of the diurnal cycles in atmospheric reanalyses over Antarctic sea ice, J. Geophys. Res., 118, 4194-4204, doi:10.1002/jgrd.50336, 2013.

Turner, J., Colwell, S. R., Marshall, G. J., Lachlan-Cope, T. A., Carleton, M., Jones, P. D., Lagun, V., Reid, P. A., and Iagovkina, S.: Antarctic climate change during the last 50 years, Int. J. Climatol., 25, 279-294, 2005.

Uppala, S. M., Kållberg, P. W., Simmons, A. J., Andrae, U., Da Costa Bechtold, V., Fiorino, M., Gibson, J.K., Haseler, J., Hernandez, A., Kelly, G. A., Li, X., Onogi, K., Saarinen, S., Sokka, N., Allan, R. P., Anderson, E., Arpe, K., Balmaseda, M. A., Beljaars, A. C. M., Van De Berg, L., Bidlot, J., Bormann, N., Caires, S., Chevallier, F., Dethof, A., Dragosavac, M., Fisher, M., Fuentes, M., Hagemann, S., Hólm, E., Hoskins, B. J., Isaksen, L., Janssen, P. A. E. M., Jenne, R., Mcnally, A. P., Mahfouf, J.-F., Morcrette, J.-J., Rayner, N. A., Saunders, R. W., Simon, P., Sterl, A., Trenbreth, K. E., Untch, A., Vasiljevic, D., Viterbo, P., and Woollen, J.: The ERA-40 re-analysis, Q. J. Roy. Meteor. Soc., 131, 2961-3012 doi:10.1256/qj.04.176, 2005

van den Broeke, M.: Strong surface melting preceded collapse of Antarctic Peninsula ice shelf, Geophys. Res. Lett., 32, L12815, doi:10.1029/2005GL023247, 2005.

van Lipzig, N. P. M., Marshall, G. J., Orr, A., and King, J. C.: The relationship between the Southern Hemisphere annular mode and antarctic peninsula summer temperatures: analysis of a highresolution model climatology, J. Climate, 21, 1649-1668, 2008.

Vaughan, D. G. and Doake, C. S. M.: Recent atmospheric warming and retreat of ice shelves on the Antarctic Peninsula, Nature, 379, 328-331, 1996.

Vaughan, D. G., Marshall, G. J., Connolley, W. M., Parkinson, C., Mulvaney, R., Hodgson, D. A., King, J. C., Pudsey, C. J., and Turner, J.: Recent rapid regional climate warming on the Antarctic Peninsula, Clim. Change, 60, 243-274, 2003.

Vihma, T., Uotila, J., Cheng, B., and Launiainen, J.: Surface heat budget over Weddell Sea: buoy results and model comparisons, J. Geophys. Res., 107, 5-1-5-15, doi:10.1029/2000JC000372, 2002 . 